\title{
Corporate Share Repurchases in the 1990s: What Role Do Stock Options Play?
}

\author{
Scott J. Weisbenner
}

\author{
Federal Reserve Board
}

November 1998, revised April 2000

\begin{abstract}
$\underline{\text { ABSTRACT }}$
This paper investigates how the growth of stock option programs has affected corporate payout policy. Given that earnings per share (EPS) is widely used in equity valuation, some corporations may opt to repurchase shares to avoid the dilution of EPS that results from past stock option grants. Executives may also prefer distributing cash by repurchasing shares or retaining more earnings, as opposed to increasing dividends, to enhance the value of their own stock options. This paper tests the importance of these two hypotheses using crosssectional and panel data on stock option programs. I find that stock options granted to top executives affect payout policy differently than do stock options granted to other employees. Option grants in general are associated with increased share repurchases and increased total payouts. However, the larger is the executives' holding of stock options, the more apt the firm is to retain more earnings and curtail cash distributions. Analysis of panel data for a sample of large firms suggests that firms conduct an ongoing repurchase of shares over the life of an option that undoes much of the dilution to EPS that results from past stock option grants.
\end{abstract}

JEL Classification: G30, G35

Key Words: share repurchase, stock option, payout policy

This paper is a revised version of chapter one of my MIT Ph.D. dissertation. I am grateful to Jeff Brown, Jon Gruber, Jerry Hausman, Nellie Liang, Steve Oliner, seminar participants at Columbia University, the University of Illinois, the Federal Reserve Bank of New York, and the Federal Reserve Board of Governors, and in particular Jim Poterba for helpful comments. Barry Cheung's assistance in collecting data from proxy statements and annual reports was greatly appreciated. The National Science Foundation provided support for this research. This research was carried out using the NBER Asset-Pricing database. The views presented are solely those of the author and do not necessarily represent those of the Federal Reserve Board or its staff.

Contact information:

Scott Weisbenner

Federal Reserve Board, Mail Stop 89

Washington, DC 20551

phone: (202) 452-3080, fax: (202) 452-5296, e-mail: sweisbenner@ frb.gov 
The past two decades have seen a dramatic change in corporate payout policy, as firms are increasingly using share repurchases to distribute cash. For the S\&P 500, stock buybacks have grown from $10 \%$ of dividends in 1980 to actually surpassing dividend payments over 1997-98. Particularly striking is the surge in share buybacks in the mid-1990s, as share repurchases doubled from 1994 to 1996. Why are firms repurchasing so much of their stock, and why do firms keep buying back shares despite soaring valuations?

At the same time repurchases have risen, the use of stock-based compensation has taken off. Three quarters of the members of the S\&P 500 from 1994 to 1998 increased stock option grants over the period. For the S\&P 500 as a whole, stock option grants rose from $1.0 \%$ of shares outstanding in 1994 to $1.6 \%$ of shares outstanding in 1998. The size of stock option programs grew over $40 \%$ over the four-year span, with outstanding stock options representing 6.3\% of shares outstanding at the end of 1998 (based on 10-K filings). Clearly, the growth in option programs could be connected with the surge in share repurchases. The question is why? This paper considers whether the dilution of accounting earnings per share (EPS), which results from option programs, is a contributing factor to stock repurchases.

While current accounting standards do not require a firm's earnings to reflect the value of stock options granted to employees during the current year, they do attempt to account for the potential dilutive effect of outstanding options on an existing shareholder's claim on the firm. Reported EPS divides the level of earnings by the sum of common shares outstanding and common stock equivalents, which are added to reflect outstanding dilutive securities. The granting of stock options will increase the number of shares over which earnings are divided, thus diluting EPS. The cost of an option program is therefore ultimately reflected by an erosion of earnings per share. This is important, as the EPS number is widely used to evaluate firm performance and determine stock valuation. ${ }^{1}$ Further, executive compensation may also be tied in part to accounting measures, such as earnings per share.

In order to counter this dilution, the firm can repurchase stock. Repurchasing shares reduces shares outstanding, and the cash used to purchase the stock is not deducted from earnings. In many circumstances, EPS will be boosted when a firm repurchases stock. Thus, an ongoing share buyback program can at least partially undo the dilution that results from stock option grants, making the real costs firms are incurring from stock options less apparent. This illustrates why Charles Clough, chief investment strategist at Merrill Lynch, refers to share repurchases as "a pure earnings management scheme" (The Wall Street Journal, February 22, 1999). To the extent that stock prices are sensitive to reported earnings per

\footnotetext{
1 There is both anecdotal and empirical evidence of the importance placed upon reported EPS by investors, financial advisors, and managers (examples include Andrade (1999), Barth, Elliot, and Finn (1995), Burgstahler and Dichev (1997), and Degeorge, Patel, and Zeckhauser (1999)).
} 
share, some firms may have an incentive to repurchase shares to undo the dilutive effect of option programs. I'll refer to this motivation as the "undo dilution" hypothesis.

Stock option programs could potentially influence corporate payout policy through a second channel. Jolls (1998) and Fenn and Liang (2000) focus on the form of executive compensation as an explanation for the growth in share repurchases. The popular press also cites executive compensation as contributing to the change in corporate payout policy (The Economist, August 7, 1999 and April 25, 1998, and Business Week, April 21,1997). An executive with stock options has an incentive to avoid paying dividends. A dividend payment will reduce the stock price and the value of outstanding options, whereas a repurchase of shares or greater earnings retention will not. Murphy (1998) reports that about one percent of CEOs with options have dividend protection. That means that any dividends paid on a stock will typically not be paid to those holding options on that stock. Thus, firms whose executives hold more options may repurchase more stock and/or retain more earnings to maximize the value of their option holdings. The distribution decisions of the firm will not solely reflect shareholders preferences, but will also depend on how the wealth of the person(s) making those decisions, the agent, is affected. I'll refer to this as the "agency" hypothesis.

There is variation both in the use of stock-based compensation and the option holdings of upper management across corporations. The undo dilution hypothesis and the agency hypothesis may give different predictions for a firm's future payout policy. For example, corporations are increasingly granting stock options to non-executives. ${ }^{2}$ Under the agency hypothesis, this development would not substantially affect payout policy. However, it would have important implications for future share repurchases and earnings retention if firms care about share dilution and preventing erosion in earnings per share. This paper uses data on both total outstanding options and the portion held by the top five executives for a cross-section of over 800 firms at the end of 1994 to test what effect option programs have upon payout policy and to determine the relative importance of the two hypotheses. The use of data on total options and those held by top executives distinguishes this paper from the previous work in this area.

Indeed, I find that stock option grants to top executives affect payout policy differently than do stock option grants to other employees. Two links between option programs and payout policy emerge in the sample, providing support for both hypotheses. First, while the overall size of a firm's option program is a strong predictor of subsequent share repurchases, there is no correlation between the option holdings of the top five executives and stock buybacks. Estimates suggest that a five percentage point increase in total

\footnotetext{
2 A recent survey by ShareData indicates that the number of companies that grant options to all of their workers has increased substantially over the past three years (Forbes, May 18, 1998). Only 15\% of corporations currently award stock options to senior management only (Institutional Investor, November 1999).
} 
options outstanding (normalized by shares outstanding) is associated with a $2 / 5$ percentage point increase in the fraction of shares repurchased, which also boosts total firm payouts. Consistent with the undo dilution hypothesis, the link between options and stock repurchases is strongest for firms with higher stock returns. A rising stock price makes stock options deeper in-the-money, and thus increases their dilutive effect upon EPS.

Second, while option grants in general are associated with increased payouts and decreased earnings retention, the larger is the executives' holding of stock options, the more apt the firm is to retain more earnings and curtail cash distributions. This finding is consistent with the well-documented negative relationship between dividends and managerial stock options (Lambert, Lanen, and Larcker (1989) and Fenn and Liang (2000)). The relationship does not appear to be explained by differences in investment opportunities across firms. This result supports the agency hypothesis, namely that the distribution decision of a firm is influenced by executive compensation. It also suggests that any option-induced dividend reductions to enhance the value of executives' options have primarily been used to retain more earnings.

To test the robustness of the results obtained from the cross-section, and provide additional evidence for the undo dilution hypothesis, the paper also utilizes a decade-long panel data set on stock option programs for 144 large firms. This unique data set enables me to study the timing of any adjustment in payout policy in response to stock option grants. Stock options do not dilute accounting earnings per share immediately when granted, nor when the options are exercised, but rather gradually over the life of the option, as the price of the stock rises above the exercise price (the option is deeper in-the-money). If firms are concerned with undoing the erosion to earnings per share resulting from stock options, this leads to a testable prediction for the timing of stock buybacks. Indeed, analysis of the panel of large firms suggests a gradual repurchase of shares over the life of the option to undo much of the dilution to earnings per share that results from past stock option grants. Estimates suggest that the presence of stock option programs has boosted the fraction of shares repurchased by roughly $1 / 2$ percentage point annually for these large firms in the mid to late 1990s. Further, the increase in stock option grants in the nineties has increased the fraction of shares repurchased by an estimated 1/5 percentage point from 1994-98. This accounts for roughly a third of the increase in repurchases from 1994-98.

These results bear on such issues as the interplay between accounting practices and economic behavior, how executive compensation affects firm payout policy, firm valuation, and future trends in corporate distributions. Repurchasing shares in response to stock option grants could be an earnings management tool to undo dilution to earnings per share. Since rising stock prices increase the dilutive 
effect of outstanding options upon earnings per share, the undo dilution motivation may help explain why firms are regularly buying back shares despite soaring valuations. Further, the cash flow needed to finance these share repurchases and avoid dilution may reduce funds available to finance future investment. Given the growth in stock-based compensation in corporate America, an important question raised by this paper is do investors anticipate how stock options may influence future corporate payout policy and earnings retention? Does the market capitalize the use of stock-based compensation into share prices?

The paper will proceed as follows. Section 1 describes the accounting treatment of stock options in more detail. There I also review the relevant literature on earnings management, discuss whether accounting measures like earnings per share "matter" to investors and managers, and illustrate the growth of stock option programs and their potential dilutive effect on EPS. Previous work regarding how stock options may influence payout policy is discussed in Section 2. The estimation strategy and data set details are provided in Section 3. Section 4 presents and discusses empirical cross-sectional relationships between option programs, executive option holdings, and payout policy. An analysis of the timing of share repurchases in response to stock option grants and exercises is presented in Section 5. Section 6 concludes.

\section{Accounting for Stock Options and Earnings Management}

\subsection{Accounting for Stock Options}

Unlike cash-based compensation, Accounting Principles Board Opinion 25 (APB 25) usually does not require any expense be recorded when the firm grants employee stock options. ${ }^{3}$ A few years ago, the Financial Accounting Standards Board (FASB), attempted to amend APB 25 with a rule that would have required companies to make explicit the fair value of option grants, and deduct the cost against current earnings. After intense debate, companies were not required to recognize the fair value of option grants as a compensation expense. As a compromise, FASB issued the Statement of Financial Accounting Standard No. 123 (SFAS 123) in October 1995. This ruling allows firms to continue to apply the favorable accounting treatment of options that exists under APB 25, but requires firms (starting in fiscal years beginning after December 15,1995$)$ to disclose in a footnote the impact upon earnings if the fair value of stock options were counted as an expense, with the cost divided across the vesting period of the option grants.

\footnotetext{
3 The firm does not recognize any compensation expense if the exercise price of a fixed-plan stock option equals or exceeds the current market price of the stock. If the exercise price is less than the current market price, then the difference is recorded as an expense. The terms of a fixed-plan option, such as the exercise price, life, and vesting schedule, are known when granted and not contingent upon future events.
} 
While stock option grants to employees may not depress current earnings directly, they will reduce future earnings per share. Accounting standards have long recognized that stock options and convertible securities dilute existing shareholders' claims on a firm's earnings. Starting in fiscal years ending after December 15, 1997, Statement of Financial Accounting Standard No. 128 (SFAS 128) requires companies to report both basic and diluted earnings per share. Basic EPS is earnings available to common shareholders divided by the weighted average of shares outstanding. Diluted EPS increases the number of shares in the denominator to reflect the dilutive effects of convertible securities and stock options, and adds back to earnings interest payments that would not have to be made by the firm upon the conversion of bonds/preferred stock to common stock. Prior to December 15, 1997 firms were required to report primary earnings per share under the guidelines established by Accounting Principles Board Opinion No. 15 (APB 15). The previously reported primary EPS is very similar to diluted EPS, and diluted/primary EPS is the measure typically used by analysts and investors. All subsequent references to earnings per share will refer to diluted/primary earnings per share.

The treasury stock method for computing the dilution resulting from options is used when calculating diluted EPS, and was also used when calculating primary EPS. This method assumes that the proceeds received from the exercise of options are used to repurchase stock. It adds to the denominator the difference between the number of shares that would be issued upon exercise of all in-the-money options and the number of common shares that could be purchased with the proceeds received when the options are exercised. ${ }^{4}$ In other words, when calculating the number of shares over which earnings are to be divided for EPS, each outstanding share of stock is given a weight of one, and each in-the-money outstanding stock option is given a weight of $(\mathrm{P}-\mathrm{X}) / \mathrm{P}$, where $\mathrm{P}$ is the stock price and $\mathrm{X}$ is the option's exercise price. ${ }^{5}$

Thus, barring any repurchase of shares, stock options will have a dilutive effect upon subsequent earnings per share, which will make the cost of option-based compensation more explicit. This dilution does not occur immediately at the time of grant, nor when the option is exercised, but gradually over the life

\footnotetext{
${ }^{4}$ The shares added to common shares outstanding when calculating the denominator of EPS are referred to as incremental shares or common stock equivalents. Only in-the-money options are counted as incremental shares. Thus, diluted EPS is not affected by options granted recently at or above the current market price, or previously granted options that have fallen out-of-the-money. Core, Guay, and Kothari (1999) discuss how SFAS 128 fails to adequately take into account the economic dilutive effect of stock options, and propose an alternative method to calculate the dilutive effect of outstanding stock options upon EPS. This paper tests whether firms appear to repurchase stock in a pattern that is consistent with countering the accounting dilution to EPS that results from stock options.

5 The treasury stock method assumes that the proceeds received upon exercise are used to repurchase a company's stock, reducing the number of shares to be added to outstanding common stock. The exercise price that the employee pays represents the primary proceeds received. In some circumstances, the exercise of an option will result in additional proceeds, such as a tax benefit that is credited to additional paid-in capital, which would allow the firm to repurchase more stock. Hence, the weight given to the outstanding option would be less than (P-X)/P.
} 
of the option as the price of the stock rises above the option's exercise price. When the firm repurchases stock, it shrinks the number of shares over which earnings are divided. The cash used to finance the repurchase will reduce paid-in capital, but will not directly affect earnings. The repurchase may depress the level of future earnings by reducing cash on hand, but such effects will often be minimal. For example, if the funds used to repurchase stock would have instead been distributed to shareholders in another form, perhaps via dividends, then the level of earnings will not be changed. If the share repurchase is financed by a reduction in holdings of cash or other low-return liquid assets, the interest income foregone is also minimal. ${ }^{6}$ In these circumstances, the share repurchase will boost earnings per share. As will be discussed below, some firms may have incentives to combine an ongoing share repurchase program with an option program to at least partially undo the erosion to EPS.

\subsection{Earnings Management}

This raises the question: Why should firms care about accounting earnings per share? Is there any evidence that firms manage earnings to manipulate accounting measures? After all, a traditional valuation model in corporate finance would say a firm's value is based on the present discounted value of expected future cash flows. Differences in reported earnings per share due to accounting conventions rather than fundamentals should be irrelevant to the market.

First, the structure of executive compensation may provide incentives to manage earnings and EPS. A 1993 survey by the Hay Group, Inc., reports that one quarter of surveyed corporations base annual bonuses at least in part on earnings per share and 30\% tie long-term performance based plans to earnings per share. The annual bonus is a nontrivial component of an executive's compensation. For example, nearly $7 / 8$ of CEOs receive an annual bonus and the average annual bonus is $\$ 600,000$ in a sample of over 800 large and medium capitalization firms at the end of 1994. Healy (1985), Holthausen, Larker, and Sloan (1995), and Guidry, Leone, and Rock (1999) provide some evidence that managers manipulate earnings to maximize the present value of bonus plan payments.

Second, EPS is a key statistic used to evaluate a firm's performance and valuation. There is much anecdotal evidence on the importance of EPS to investors, financial advisors, and managers. Wasserstein (1998) states, "With many investors focused on earnings, companies often hesitate to take on dilutive

\footnotetext{
${ }^{6}$ How a share repurchase impacts EPS will depend upon the marginal source of funds for the repurchase. If the stock buyback is financed by reducing holdings of cash or cash equivalents or by issuing debt, then EPS will be boosted with the repurchase if: [ $(1$ - corporate tax rate $) *$ interest rate] < [earnings-price ratio]. Presumably, the corporation uses liquid assets with a low rate of return to finance the repurchase program, suggesting a minimal loss of interest income, and thus a likely increase in EPS. However, given rising P/E ratios and rising interest rates, a stock buyback may actually lower EPS for some firms.
} 
transactions." Corporations often emphasize earnings per share and growth in EPS in their annual report to shareholders (see Barth, Elliot, and Finn (1995) and Burgstahler and Dichev (1997) for numerous examples). Barth, Elliot, and Finn (1995) find firms with a pattern of earnings increases command higher price-earnings ratios after controlling for the level of earnings. This premium is substantially reduced, though, when the established pattern of earnings increases is broken. DeAngelo, DeAngelo, and Skinner (1996) also present evidence that investors punish firms for breaking a pattern of consistent EPS growth.

Firms seem to care about earnings per share, especially relative to benchmarks such as last year's earnings or analysts' expectations. To the extent that stock prices are sensitive to reported earnings per share, some firms may have an incentive to manage EPS. Relative to EPS a year earlier, Burgstahler and Dichev (1997) and Degeorge, Patel, and Zeckhauser (1999) both find an unusually small occurrence of small EPS decreases and an unusually high frequency of small increases in EPS. The latter study also finds a similar pattern around analysts' earnings forecasts. Such discontinuities in the distribution of reported earnings suggest firms have incentives to avoid dilutive transactions and mange earnings per share.

Matsunaga (1995) presents evidence that firms that use income-increasing measures to expense depreciation and value inventory are also more apt to grant stock options. The key question is how well does the market sort through this accounting information. Do transactions which boost earnings per share, or conversely dilute EPS, affect stock returns even if the change in EPS merely reflects accounting practices as opposed to real cash flow?

Andrade (1999) provides some evidence on this issue. The method of accounting for an acquisition (pooling-of-interest vs. purchase) and the method of payment (cash vs. stock) can lead to different EPS numbers post merger. He tests whether the part of future EPS changes that is due to accounting conventions and acquisition financing decisions, rather than fundamentals or synergies, affects acquirer stock prices. Using a sample of 224 mergers/acquisitions, he finds that EPS accretion attributable to accounting has a positive and significant effect upon abnormal returns of the acquirer for up to 18 months after the deal.

Summing up, these studies seem to indicate that reported EPS matters, and can influence corporate decisions. ${ }^{7}$ Corporations seem to avoid transactions that will dilute earnings per share, either because of

\footnotetext{
${ }^{7}$ If earnings management affects stock prices, then firms preparing for capital market activities, like a public equity offering, will have an incentive to manipulate reported earnings to boost share price and thus increase proceeds from the transaction. Researchers have attempted to test for the manipulation of reported earnings prior to such capital market activities, and generally find some evidence of earnings management. Examples include Teoh, Welch, and Wong (1998a) and Rangan (1998) on seasoned equity offerings, Teoh, Welch, and Wong (1998b) on IPOs, and Erickson and Wang (1999) on stock swap mergers.
} 
the reaction from analysts and investors that would provoke or because of the resultant impact upon an executive's own bonus. Granted, the potential dilution resulting from stock option programs may be slight for many firms. However, the typical difference in earnings per share relative to last year or relative to analysts' expectations is fairly small. For example, Degeorge, Patel, and Zeckhauser (1999) report that the median difference from analysts' forecast is zero cents. Thus, undoing the dilutive effect of past stock option grants could be part of an earnings management strategy and a possible motivation to repurchase stock.

\subsection{Growth and Cost of Stock Option Programs}

The use of employee stock options has increased substantially over the past decade. Table 1 displays the growth in the stock option overhang, defined as outstanding options and shares reserved for future grants normalized by shares outstanding, for NYSE and S\&P 500 firms from 1985 to 1996. The median option overhang grew $60 \%$ over this period, and $75 \%$ when weighted by market value. The median option overhang at the start of 1996 was $7.2 \%$ of shares outstanding.

One way to measure the erosion to EPS that results from dilutive securities, primarily options, is to compute how much lower diluted earnings per share is relative to basic earnings per share (the dilution wedge). Core, Guay, and Kothari (1999) report that stock options make up more than $80 \%$ of the additional shares added to outstanding shares when computing diluted earnings per share. The upper panel of Table 2 displays estimates of the dilution from option programs at the end of 1998. Outstanding dilutive securities reduce reported EPS by $2.2 \%$ for the S\&P SuperComposite 1500 firms with positive earnings. ${ }^{8}$ One eighth of corporations have a dilution wedge exceeding 5 percent. Dilutive securities reduce reported EPS for mid- and small-capitalization firms by $2.7 \%$, compared with $2.2 \%$ for the members of the S\&P 500. The dilution wedge is twice as large in the technology sector, where the use of stock options is more intensive.

This discussion illustrates that option programs can potentially erode EPS. For example, common stock equivalents boosted the denominator of diluted EPS by $14 \%$ for Merrill Lynch and $10 \%$ for Microsoft in 1998. However, Merrill Lynch has repurchased 15\% of its shares, and Microsoft has repurchased $7 \%$ of its shares since 1996 . Undoing the dilutive effect of stock options through a share repurchase program could be an earnings management tool. A survey of 1600 chief financial officers in the November 1999 issue of Institutional Investor reports that three out of five CFOs conduct an ongoing share repurchase program to prepare for the exercise of stock options. However, only one in eight worry

\footnotetext{
${ }^{8}$ Firms that suffer a net loss do not add incremental shares to shares outstanding when calculating diluted EPS since doing so would be antidilutive (would make EPS less negative). Theoretically, option holders participate in both increases and decreases in firm value, suggesting there should be no asymmetry in treatment.
} 
that dilution from stock options may reduce earnings per share within the next five years. Of course, erosion to EPS may not be a concern because of the ongoing buyback program. Or stock options may influence payout policy through a channel other than the undo dilution hypothesis. For example, executives may adjust payout policy to enhance the value of their stock options.

\section{Alternative Channel for Stock Options to Influence Payout Policy}

The past decade has witnessed a transformation in how executives are compensated. While annual cash-based compensation for CEOs at large U. S. corporations has grown about $50 \%$ in real terms from 1985 to 1994, the average value of stock option grants has nearly tripled (Hall and Liebman (1998)). The value of annual stock-based compensation now exceeds the value of cash-based salary for many top executives.

The changing structure of executive pay may provide upper management incentives to adjust payout policy. ${ }^{9}$ This is the agency hypothesis outlined in the introduction. Upper management may care about the composition of firm distributions because firms rarely offer dividend-protected stock options. ${ }^{10}$ This means that any dividends paid on a stock will not be paid out to those holding options on that stock. This can have a non-trivial effect on stock option value. For example, assuming an option life of ten years, stock volatility of $30 \%$, and a risk-free rate of 5\%, reducing the dividend yield from .02 to .01 would increase the Black-Scholes value of a stock option 18 percent and eliminating the dividend entirely would increase its value by 39 percent. Lambert, Lanen, and Larcker (1989) point out that since most executive stock option plans are not dividend-protected, the value of the option will decline with future dividend payments. The authors provide evidence that this affects payout decisions, as they find that dividends are reduced relative to their expected levels after the adoption of an executive stock option plan.

To test the agency hypothesis, Jolls (1998) collects a sample of firms announcing share repurchases or dividend increases in the Wall Street Journal, and compares them to a random sample of

\footnotetext{
9 Researchers have also examined whether the use of leverage (Berger, Ofek, and Yermack (1997)) or voluntary liquidation decisions (Mehran, Nogler, and Schwartz (1998)) is influenced by CEO stock options and stock ownership.

${ }_{10}$ Murphy (1998) reports that about one percent of CEOs with options have dividend protection. Fenn and Liang (2000) note that firms may not dividend-protect options because they would have to realize the accruing dividend as a compensation expense. The firm may also have an incentive to not dividend-protect options if shareholders wish to encourage upper management to substitute repurchases for dividends.
} 
firms that did not announce a repurchase or dividend increase. ${ }^{11}$ She concludes that firms that rely on stock options to compensate their top executives are more apt to repurchase stock.

Fenn and Liang (2000) also examine how corporate payout policy is affected by executive stock incentives. They find that there is no relationship between managerial stock ownership and payout policy in a broad cross-section of 1100 nonfinancial firms, but that stock ownership increases payouts for a subset of firms with the highest agency costs. They also provide evidence that top management options are positively correlated with share repurchases and negatively correlated with dividend payments, and interpret this evidence as suggesting a substitution of share repurchases for dividends. As Jolls does, they conclude that the repurchase decision is influenced by the compensation of upper management.

It is important to note, though, that the value of an executive's outstanding options will be the same whether an option-induced reduction in dividends is used to repurchase stock or retain more earnings (assuming no signaling effect). If management has a target level of cash payouts, then any reduction in dividends would likely be offset by increased stock repurchases. If management does not have a target level of cash payouts or believes its stock is overvalued, it may instead retain more earnings. Thus, the agency hypothesis predicts a positive correlation between upper management options and share repurchases and/or earnings retention.

The use of data on both total options and those held by top executives distinguishes this paper from previous work, and allows me to empirically differentiate between the undo dilution hypothesis and the agency hypothesis. It is important to establish which is driving the link between stock options and payout policy. For example, corporations are increasingly granting stock options to non-executives. Under the agency hypothesis, this development would not substantially affect payouts. However, it would have important implications for future stock repurchases and earnings retention if firms care about share dilution. This paper exploits a cross-sectional data set on total options outstanding and the fraction held by top executives and a panel data set on stock option grants to test what effect option programs have upon payout policy and to determine the relative importance of the two hypotheses.

\section{Empirical Strategy and Data}

\subsection{Empirical Strategy}

11 Using share repurchase announcements as opposed to actual distributions can lead to a misclassification of firms. Repurchase programs are generally conducted over many years following an announcement (Stephens and Weisbach (1998)), so many firms repurchasing stock in year $\mathrm{t}$ would not have made an announcement in year $\mathrm{t}$. 
I now employ a variety of estimation techniques to disentangle what is driving the link, if any, between option programs and firm payout policy. There are many other motivations to repurchase stock (e.g., signaling undervaluation or strong future earnings prospects, distributing free cash flow, and minimizing the tax burden of shareholders), for which my estimation strategy must control. ${ }^{12}$

Grullon and Michaely (2000) analyze whether firms substitute share repurchases for dividends to reduce a shareholder's tax liability. From a tax perspective, individuals should have the biggest preference for share buybacks. Thus, one would expect a positive correlation in the cross-section between share repurchases and direct individual ownership of the corporation. Clearly, the level of payouts will depend upon a firm's cash flow. Distributions and repurchases are less costly to make for firms with a high level of cash flow, controlling for investment opportunities. I break cash flow into two components: operating income and non-operating income. Guay and Harford (2000) and Jagannathan, Stephens, and Weisbach (2000) both emphasize the flexibility of share repurchases as a means to distribute cash flow, particularly cash flows that are not likely to be sustained indefinitely. The latter paper hypothesizes that repurchases will be more closely tied to temporary cash flow, proxied for by non-operating income, than permanent cash flow, proxied for by operating income.

The decision to repurchase shares should also depend upon the marginal investment opportunities of the firm (proxied for by the ratio of the market value to the book value of assets). Firms with good investment opportunities may enhance firm value by using cash flow to finance investment as opposed to distributing it to shareholders, and vice versa (Jensen (1986)). The "traditional" view of dividend taxation (Poterba and Summers (1985)) suggests firms make adjustments on the equity repurchase/issuance margin to accommodate the capital expenditures of the firm. Another motivation to repurchase stock is undervaluation, proxied by the firm's stock return during the previous year. Previous work also suggests such factors as the leverage of the firm and firm size may also influence the decision to repurchase stock. A negative correlation between outstanding debt and share repurchases could reflect that using cash for distributions is less desirable the more highly leveraged a firm is (greater financial distress) or that debt can be viewed as a substitute to payouts to purge free cash flow (Jensen (1986)). Firm size (book value of total assets) serves as a proxy for financing costs, asymmetric information, variance in cash flows, etc.. Finally, there may be industry-specific differences in growth opportunities or corporate governance that may

Usem, Schulman, and Brown (1995) and Stephens and Weisbach (1998) document that a nontrivial number of firms do not follow through on share repurchase announcements.

12 Dann (1981), Vermaelen (1981), Asquith and Mullins (1986), Comment and Jarrell (1991), Ikenberry, Lakonishok, and Vermaelen (1995), and Stephens and Weisbach (1998) focus on asymmetric information/stock undervaluation, Denis (1990) and Bagwell (1991) focus on takeover deterrence, and Jagannathan, Stephens, and 
influence payout policy. Thus, specifications will include controls for the three-digit SIC group classification.

Similar to Jagannathan, Stephens, and Weisbach (2000), Bagwell and Shoven (1988), and others, I will estimate reduced form regressions of a firm's payout policy of the form:

$$
\begin{aligned}
\left(\text { Payout Policy }_{i}\right)=\beta_{0}+ & \beta_{1} * \text { TOTAL OPTIONS } \\
i & +\beta_{2} * \text { EXECUTIVE OPTIONS }_{i}+ \\
& \beta_{3} * \text { INDIV. OWNERSHIP } \\
i & +\beta_{4} * \text { FINANCIAL CHARACTERISTICS }_{i}+ \\
& \text { INDUSTRY EFFECTS }_{i}+\varepsilon_{i}
\end{aligned}
$$

Payout Policy will be defined primarily as the level of share repurchases, but regressions of total payouts and earnings retention will also be estimated. Since a number of firms do not repurchase shares or make any distributions, a Tobit model will often be assumed to estimate specification (1). For this study, the primary focus will be on the magnitude and importance of $\beta_{1}$ and $\beta_{2}$, the coefficients on the option variables. The undo dilution hypothesis predicts a positive correlation between total options outstanding, normalized by shares outstanding, and share repurchases. The agency hypothesis predicts a positive correlation between upper management options and share repurchases and/or earnings retention. Executives concerned about the value of their stock options may prefer substituting share repurchases and/or greater earnings retention for dividends. Therefore, the option holdings of the top five executives, normalized by common shares outstanding, are also included in the regressions. This variable can loosely be interpreted as how much the total value of the stock underlying the executives' option holdings is reduced if the firm pays out an additional dollar of dividends. ${ }^{13}$ The inclusion of the other covariates in the regression is meant to control for additional factors, outlined above, that may influence payout policy. Payout policy is measured during year $\mathrm{t}$, with the explanatory variables measured at the end of year $\mathrm{t}-1$.

This paper will utilize two data sets. First, I estimate specification (1) using data on employee stock option programs and option holdings of top executives for a cross-section of over 800 firms at the end of 1994. This data set is discussed below in Section 3.3, and empirical results are presented in Section 4.

A criticism of any cross-sectional analysis is that it cannot rule out that some omitted firm-specific effect is driving the results. For example, omitted factors such as management skill or corporate

Weisbach (2000) focus on the flexibility of share repurchases in distributing temporary cash flows as motivations for repurchasing stock. 
governance could influence both payout policy and the use of stock options, perhaps explaining the correlation between the two in the data. Therefore, data on stock option grants and exercises were collected for the 144 current non-bank members of the S\&P 100, Dow Jones Industrial index, and S\&P 500 technology sector over the past decade. This enables estimation of specification (2):

$$
\begin{aligned}
& \text { (Change in Shares Outstanding } \left._{i, t}\right)=\alpha_{0}+\alpha_{1} * \text { OPTION EXERCISES } S_{i, t}+\alpha_{2} * \text { OPTION GRANTS }_{i, t} \\
& +\alpha_{4} * \text { FINANCIAL CHARACTERISTICS }{ }_{i, t}+ \\
& \text { FIRM EFFECTS }_{i}+\text { YEAR EFFECTS }_{t}+\varepsilon_{i, t}
\end{aligned}
$$

The use of panel data in Section 5 allows me to examine the timing of share repurchases in response to stock option grants and exercises, and to test whether the timing is consistent with the undo dilution hypothesis.

\subsection{Interpretation of Causality}

Caution must be exercised when interpreting the relationship between firm payouts and other financial variables such as investment, cash flow, and debt that may be partly endogenous. Obviously, firms make decisions over many financial variables simultaneously. Since most models focus on investment opportunities and decisions as the primary determinant of firm value, it is natural to think of distributions responding on the margin to lagged investment rather than the reverse. However, since the form of distributions can potentially impact future investment through changing the user cost of capital, feedback effects are possible. Given perfect measurement of investment opportunities (market-to-book ratio), the coefficient on lagged cash flow can also be given a causal interpretation. Mismeasurement of investment opportunities, though, could potentially cloud interpretation of the coefficient on cash flow. While the effect of the non-option variables upon payout policy is of interest, this is not the focus of this paper. The estimated link between option programs and payout policy, which is the focus, is robust to the inclusion/exclusion of the firm financial variables in the regression.

If the compensation board wants to distribute a fixed amount of wealth to its employees via stock options, it may adjust option grants to reflect the past distribution policy of the firm. Thus, the interpretation of the options coefficient in a cross-sectional regression could also be clouded by reverse causality. However, to the extent it is present, this endogeneity would bias downward the options coefficient in a share repurchase reduced form. For example, suppose there are two firms that are

${ }^{13}$ If the executives' options are not deep-in-the-money, this will overstate the decline in value of outstanding options from a $\$ 1$ dividend paid by the firm. Since I only have data on executive options for one year, I do not have sufficient data on the characteristics of the option portfolio to construct the slope of the option value curve. 
identical, except one pays dividends and the other repurchases shares. If each firm wants to distribute the same amount of wealth to employees via stock options, the dividend-paying firm will have to grant more options to compensate for the reduction in the option value when a dividend is paid.

A cross-sectional analysis cannot rule out that some firm-specific effect is driving the correlation between options and payout policy. Analysis of a panel data set of firms allows the researcher to control for firm-specific differences that could potentially influence the decision to repurchase stock, and thus address many of the concerns raised above.

\subsection{Overview of Cross-Section Data}

The sample consists of all publicly traded companies that belonged to the S\&P 500 or the MidCap 400 at the end of 1994, or are included in one of the May 1995 Forbes 500 lists (sales, profits, assets, and/or market value), with the following exceptions. Corporations in highly regulated industries, such as banks (SIC two-digit industry 60) and utilities (SIC two-digit industry 49) are excluded. Firms that do not have an observation in Compustat in 1995 are dropped, as are firms for which data on executive options and/or total outstanding options are not available either through the annual report, $10-\mathrm{K}$, or the proxy statement. The remaining sample consists of 826 firms, which in the aggregate represents $70 \%$ of the capitalization of the NYSE and 90\% of share repurchases during 1994.

Table 3 summarizes the option programs, direct individual ownership, and payout policy for these firms. Other characteristics of the sample are reported in the Appendix. Stock option-related data were collected for firms at the end of fiscal year 1994 from proxy statements, annual reports, and 10-Ks filed by U. S. corporations. Data on the ownership of companies' equity are taken from Standard and Poor's Security Owner's Stock Guides. The Center for Research in Securities Prices (CRSP) tapes provide stock returns. All other variables are constructed from Compustat and are explained in detail in the notes in the Appendix.

Total options outstanding represent on average $5.7 \%$ of common shares outstanding at the end of 1994. Forty-five percent of firms in the sample have outstanding stock options representing over $5 \%$ of outstanding shares at the end of 1994, and fourteen percent have outstanding options representing over $10 \%$ of shares outstanding. Thirty-two firms have no stock option programs.

Proxy statements report compensation and stock option holdings for top executives. The number of executive officers covered by the proxy statement reporting requirements is usually five. ${ }^{14}$ The five reported executives have close ties to the actual operations of the firm, and thus may be able to influence

${ }^{14}$ These five executive officers include the CEO, and the four other most highly compensated officers (e.g., the chief operating officer, the chief financial officer, and two senior vice presidents). In the few cases when more or less than five are reported, total option holdings for the group are scaled to reflect five officers. 
the payout policy of the firm. On average, CEOs held about $12 \%$ of all outstanding options and the top five executive officers held about $28 \%$. The top five executive officers held over half of a firm's stock options in $12 \%$ of the sample and held less than a tenth of all options in $13 \%$ of the sample. Forty-six firms had stock option programs in which the CEO had no holdings. Figure 1 contains three histograms displaying the variation in the size of option programs and the fraction of outstanding options held by the CEO and the top five executive officers. ${ }^{15}$ The correlation between total options outstanding and the outstanding options held by the top five executives is .6 in the sample.

Standard and Poor's Security Owner's Stock Guides provide institutional ownership data which covers investment companies (mutual funds), banks, insurance companies, college endowments, and "13F" money managers. Thus, direct individual ownership (total outstanding shares less those held by institutions) excludes household holdings of corporate equity though mutual funds or pension plans. Direct individual ownership is a variable of interest because it proxies for the tax status of a corporation's shareholders. The tax differential between dividends and capital gains is largest for the individual investor. ${ }^{16}$ Therefore, my measure of individual ownership should be highly correlated with the fraction of shareholders of a firm that are most concerned about the tax consequences of distributions, reap the biggest tax advantage from capital gains as opposed to dividends, and have direct control over their shares.

Most of the firms make distributions of some sort, as three quarters pay dividends and half repurchased stock in 1995 (nearly a third repurchased more than one percent of market value). Throughout the paper, the repurchase payout rate is calculated by dividing share repurchases by the average of the beginning and end of year market value. The repurchase payout rate can be interpreted as the fraction of shares a company repurchases. The average repurchase payout for the sample in 1995 is $1.4 \%$.

My measure of dollars spent to repurchase stock warrants some discussion. Compustat reports dollars spent on repurchases of the firm's own securities (annual data item 115), which is obtained from the firm's Flow of Funds Statement. Stephens and Weisbach (1998) and Jagannathan, Stephens, and Weisbach (2000) note that the Compustat measure will overstate actual repurchases of common stock because it also includes repurchases of other securities. The Compustat measure aggregates all of the following: (1) conversion of Class A, Class B, special stock, etc., into common stock, (2) conversion of preferred stock into common stock, (3) purchase of treasury stock, (4) retirement or redemption of

\footnotetext{
${ }^{15}$ Specifications throughout the paper will focus on options outstanding for all employees and option holdings of the top five executives. The qualitative results presented in the paper also hold when "upper management" is defined as the CEO only, rather than the top five executives.

${ }^{16}$ Corporations generally pay tax on only $30 \%$ of dividends, but $100 \%$ of realized capital gains. See Dickson and Shoven (1995) for a discussion of whether mutual fund managers take into account the tax liability of their investors.
} 
common/ordinary stock, (5) retirement or redemption of preferred stock, and (6) retirement or redemption of redeemable preferred stock. I subtract any decreases in the par value of preferred stock (annual data item 130) from this repurchase measure so it is more reflective of repurchases of common stock. This adjustment reduces aggregate share repurchases by 9\%. Cook, Krigman, and Leach (1997a,b) collected data from 64 firms on actual dollars spent on repurchases of common stock. Jagannathan, Stephens, and Weisbach (2000) report, using the Cook, Krigman, and Leach data, that the median Compustat measure overstates actual repurchases of common stock by 13\%. This suggests my amended Compustat measure should be fairly accurate.

\section{Relationship between Option Programs and Payout Policy in Cross-Section}

\subsection{Basic Results of Share Repurchase Regressions}

The first four columns of Table 4 present estimates of specification (1), outlined in Section 3.1, for the level of share repurchases in 1995 (normalized by market value). I estimate a Tobit model in this case because there is a substantial mass point at zero, as half of the firms do not repurchase any stock in 1995. Total outstanding options are significantly and substantively related to stock repurchases. Consistent with Jolls (1998) and Fenn and Liang (2000), I initially find a strong correlation between executive option holdings and stock buybacks. However, once the total size of the option program is also included in the specification, there is no relationship between executive option holdings and share repurchases. The marginal effect of stock options evaluated at the sample average indicates that a five percentage point increase in outstanding options normalized by shares outstanding is associated with a .4 percentage point increase in the repurchase payout rate the next year (the average repurchase payout rate for the sample is $1.4 \%$ of market value). If stock options are exercised five years after granted on average, consistent with exercise patterns documented in Huddart and Lang (1996), the estimates would imply that firms repurchase roughly two-fifths to a half of the shares in an option grant over the life of the option (.088 marginal effect multiplied by five years).

The other covariates generally have the predicted effect. Share repurchases respond more to "temporary" non-operating income than "permanent" operating income. This is consistent with the financial flexibility of share repurchases and the results in Guay and Harford (2000) and Jagannathan, Stephens, and Weisbach (2000). Similar to earlier work, such as Bagwell and Shoven (1988), highly leveraged firms are found to be less likely to repurchase stock (this could reflect financial distress or the adjustment of the capital structure to reduce the agency costs of free cash flow). Firms with greater 
investment opportunities, as proxied for by the firm's market-to-book ratio, are significantly less likely to repurchase stock. This is consistent with explanations for payout policy that focus on agency problems and free cash flow. Nohel and Tarhan (1998) find that the positive investor reaction to tender offer share repurchases is also best explained by the free cash flow hypothesis as opposed to signaling.

Given the tax preference for individual shareholders for distributions made via stock repurchases, it is somewhat surprising that there is no cross-sectional relationship between direct individual ownership and the magnitude of stock buybacks. Dhaliwal, Erickson, and Trezevant (1999) provide evidence that taxes do matter in a different context, as they find that the proportion of institutional ownership changes around events such as a dividend initiation. These results are not necessarily incompatible, though, as omitted variables such as information differences across investors, heterogeneity in the valuation of dividends, and capital gains lock-in could potentially explain why the level of individual ownership is not correlated with payout policy at any point in time.

To gain more insight into what is driving the link between stock option and share repurchases during 1995, I included stock price appreciation during the current year in the regression and interacted the total options variable by an indicator variable for whether the firm's price appreciation was above the sample median (median was $20 \%$ in 1995). I also included interactions of the total options variable with whether the firm's market-to-book ratio and size (book value of assets) were above the sample median. The interaction of the above median market-to-book dummy with total options was .124 (standard error $=$ .063 ) and the interaction of the above median stock return with total options was .170 (standard error $=$ .069), while the interaction with firm size was insignificant. This suggests that the funding of option programs with repurchased shares is strongest for firms with high stock returns. The positive interactive term for the stock return and the total options variable is consistent with the undo dilution hypothesis. Rising prices make outstanding stock options more in-the-money, thus increasing the dilutive effect of outstanding stock options upon EPS. It is also worth noting that after interacting the price appreciation dummy with total options, the stock price appreciation variable itself becomes negatively correlated with stock buybacks in the same year and increases from .000 to -.009 (standard error is .006). This is consistent with the negative relationship between stock performance and repurchases found by Stephens and Weisbach (1998).

\subsection{Total Payouts and Earnings Retention}

The share repurchase results are consistent with the undo dilution hypothesis, but they do not imply that executive compensation does not influence payout policy. For example, executives concerned about the value of their outstanding options will have an incentive to avoid or reduce dividends. Lambert, Lanen, 
and Larcker (1989) and Fenn and Liang (2000) find a strong negative correlation between dividend payouts and executive stock options. It is not clear, though, why executives concerned about the value of their stock options would prefer substituting share repurchases for dividends as opposed to just retaining earnings. If management does not have a target level of cash payouts or believes its stock is overvalued, it may instead use an option-induced cut in dividend growth to retain more earnings. Under this line of reasoning, one would expect total payouts to be decreasing and earnings retention to be increasing with top executive option holdings in the mid-1990s.

Columns (4) - (5) of Table 4 present estimates from regressions of total payouts, the sum of stock repurchases and cash dividends on common stock. Since $19 \%$ of the firms did not repurchase stock or pay dividends in 1995, a Tobit model is assumed. This regression provides cross-sectional evidence on whether the increased repurchase of stock is associated with higher total distributions, or is largely offset by reduced dividend payouts. The estimated marginal effect of total outstanding options upon total payouts is two thirds to three quarters of the marginal effect upon share repurchases. This suggests that most of the option-induced increase in stock buybacks is not offset by a reduction in dividends, and thus total payouts are boosted. ${ }^{17}$ There is a countervailing effect, as option holdings of top executives are associated with reduced payout levels, through lower dividends, although the coefficient estimate is very imprecisely measured.

To further investigate these results, I also estimated regressions of the rate of retention of earnings over 1995-96 for firms with positive earnings over that period. To help smooth yearly fluctuations in earnings, I focus on the two-year horizon. The retention rate is defined as income before extraordinary items available for common less cash used to finance common dividends and share repurchases, divided by earnings. I estimate robust regressions because cash distributions greatly exceed earnings for some corporations over this period. ${ }^{18}$ There is an interesting dichotomy when both total options and option holdings of the top five executives are included in the specification (column 2 of Table 5). Overall, as shown in Table 5, the larger is a firm's option program at the end of 1994, the smaller is the fraction of earnings retained over 1995-96. A firm with options outstanding representing 5\% of shares outstanding,

${ }^{17}$ One quarter of the firms in the sample have never paid a dividend. Thus, increased repurchases cannot be offset by a reduction in dividends for these firms. Similar results are obtained if firms that have never paid dividends are excluded from the analysis.

18 This estimation procedure uses ordinary least squares estimates to exclude gross outliers and then works iteratively. Weighted least square regressions are performed using weights based on absolute residuals from the previous iteration. Huber weights are used until the estimates converge, at which point biweights are used until the estimates converge again. See the Stata Reference Manual Release 5, 1997:3, 168-173, Hamilton (1991), and Street, Carroll, and Ruppert (1988) for details. A median regression yields similar results. For example, the 
none being held by the top executives, would retain five percent more of earnings than a firm with no option program. This reflects the increased repurchase of stock to fund option programs for these firms. This reduced earnings retention could potentially translate into depressed future investment, which would affect future cash flows.

The results also suggest payout policy is affected by who holds the stock options (e.g., whether executives hold many options). Holding the overall size of the option program constant, firms in which the top five executives have large holdings of stock options retain significantly and substantially more of their earnings over 1995-96 relative to firms whose executives have small option holdings. The estimates suggest a firm whose upper management holds options representing $1 \%$ of outstanding shares will retain 2.7 percentage points more of earnings. The effect of executive option holdings upon earnings retention is consistent with the lack of a correlation with stock buybacks shown in Table 4 and the work on dividends cited earlier.

There is an alternative explanation for the executive option coefficient. Firms with strong growth opportunities will likely retain more earnings. The executives of these firms may wish to have more of their compensation in stock options because the good investment opportunities may translate into high future stock returns. Thus, the positive correlation between executive options and earnings retention may reflect that executives in firms with good growth prospects are granted more stock-based compensation, rather than an adjustment of payout policy by top management to increase the value of their option holdings.

One way to address the interpretation of the executive options coefficient is to test whether the relationship between executive options and earnings retention varies with firm size or a firm's market-tobook ratio. The last column of Table 5 presents the results for a regression that interacts whether a firm has a market-to-book ratio above or below the sample median and whether firm size is above or below the sample median with the executive option variable. The market-to-book ratio and firm size are both significant and substantive predictor of future earnings retention, however, the increased retention of earnings associated with executive option holdings does not vary with the market-to-book ratio or size of the firm (the interaction terms are small and insignificant).

It is worth noting that a substitution of greater earnings retention for dividends need not only reflect an adjustment of payout policy to boost the value of stock options. The granting of options to top executives may help align the interests of shareholders and managers, and serve as a substitute for a high payout ratio in controlling for agency problems. This hypothesis is an interesting topic left to future research.

coefficient on total options was -1.570 (p-value $=.066)$ and the coefficient on top executive options was 3.118 (p- 
Thus, the results from the cross-section provide evidence that stock option programs affect payout policy in a manner that is consistent with both the undo dilution and agency hypotheses. Consistent with the undo dilution hypothesis, stock option programs in general are associated with increased stock buybacks, which is largely financed by decreased earnings retention. Further, the funding of option programs with repurchased shares is stronger in the cross-section for firms that underwent greater price appreciation during the year, and hence had a greater erosion to EPS resulting from options. Consistent with the agency hypothesis, top executive option holdings influence payout policy, as increased option holdings by executives are associated with increased earnings retention.

To the extent that cross-sectional differences in investment opportunities and financial conditions are not properly controlled for, though, the interpretation of the correlation between options and stock repurchases is clouded. Further, the cross-sectional analysis sheds no light on the timing of share repurchases in response to stock option grants and exercises, and whether the timing is consistent with the undo dilution hypothesis. For example, firms may not care how stock option grants will affect EPS, and may simply repurchase shares when options are exercised to distribute the exercise proceeds to shareholders. The next section attempts to address these concerns.

\section{Stock Option Grants and Timing of Share Repurchases for Large Firms}

To supplement the findings obtained in the cross-section, I obtain data on employee stock option programs from 10-K filings for all the non-bank corporations that currently belong to the S\&P 100, Dow Jones Industrials, or S\&P 500 technology sector (as of July 1999). ${ }^{19}$ The Disclosure Inc. database that I use contains 10-K filings back to fiscal year 1988 or 1989 (depending on which month the firm's fiscal year ends), allowing me to construct an unbalanced panel of 144 firms. Nearly $90 \%$ of the firms have at least nine years of data (i.e., firm is in existence and data are available from 1990-98), and all but four firms have five or more years of data.

The sample is clearly not randomly selected, nor is it representative of the whole corporate sector. Given that data on option programs must be collected by hand, the number of firms in the sample is limited. Thus, the results obtained will shed light on whether these firms adjusted share buybacks in response to stock option programs, but should not be extrapolated beyond this group of firms. Nonetheless, the

value $=.078)$

19 Banks are excluded from the sample because Compustat does not report as much financial information for banks as for non-bank corporations. For example, Compustat does not report dollars spent on share repurchases 
behavior of these firms is of interest. The sample consistently comprises $30 \%$ of the market capitalization and between 30-40\% of share repurchases of all U. S. publicly traded firms in the 1990s. The sample also includes many option-intensive firms.

Table 6 provides summary statistics for the sample. Figure 2 augments the table by illustrating the growth in employee stock options and share repurchases for the 127 firms in the sample that were in existence and had complete option plan data during 1990-98. Stock option programs have grown steadily in the 1990s. The ratio of outstanding options to shares outstanding has grown two percentage points on average over the decade. The median program has grown from four to six percent of shares outstanding from 1990 to 1998, as stock option grants have increased from one to 1.5 percent of shares outstanding over the period. The increased granting of options today is reflected by an increased exercise of options tomorrow. The median number of stock options exercised more than doubled from 1990 to 98, averaging $1.1 \%$ of shares outstanding over all the firm-years. Because of the lag between when an option is granted and when it is exercised, exercises should continue to grow in the near term, even if grant rates level off. Firms repurchased stock $60 \%$ of the firm-years, with the average repurchase comprising $1.7 \%$ of market value from 1990 to 98 . After falling sharply in 1991, share repurchases have grown fairly steadily. The median firm repurchased one percent of its stock in both 1997 and 1998, compared with only .4\% back in 1990. Regression analysis is necessary to determine whether the growth in stock option programs in the 1990s has contributed to the growth in share repurchases.

To directly measure the timing of the share dilution/repurchase that results from stock option programs, I estimate regressions of the change in common shares outstanding, similar to specification (2) discussed in Section 3.1. The specifications include the same financial variables from Compustat that were included in the cross-sectional payout policy regressions. ${ }^{20}$ Since there is no mass at a single point, a linear specification is appropriate in this context. This is beneficial, as the linear model also allows firm fixed effects to be controlled for in the regressions. Since the firm-specific control may be correlated with financial characteristics that are included in the regression, a fixed-effect estimator is appropriate in this context. It is also worth emphasizing that the coefficients are identified by within-firm variation in the covariates. Similar to the retention of earnings regressions, I use a robust regression technique so that the estimates will not be sensitive to any outlier observations.

for banks. As a practical matter, most of the large banks have undergone significant mergers recently. This makes constructing a meaningful time series of observations difficult.

${ }^{20}$ The executive option holdings and individual ownership variables are excluded from the regressions of share dilution, as data on executive option holdings and individual ownership were not collected. Given their lack of explanatory power in the 1995 share repurchase regressions, their omission should not materially affect the results. 
If firms are concerned with undoing the erosion of earnings per share that results from stock options, this leads to a testable prediction for the timing of share repurchases/dilution. Stock options will not dilute accounting EPS immediately at the time of grant, nor when the stock option is exercised. Instead, the erosion to EPS will occur gradually over the life of the option (recall the weight given to an outstanding option when calculating the denominator of EPS is $(\mathrm{P}-\mathrm{X}) / \mathrm{P}$ where $\mathrm{P}$ is the stock price and $\mathrm{X}$ is the exercise price of the option). Indeed, when the stock option is exercised, EPS will generally be unaffected. ${ }^{21}$ The dilutive effect of options is already built into the EPS number. This suggests that the firm will repurchase shares in response to grants, not exercises. In other words, firms concerned about dilution will repurchase shares before the options are exercised, and the coefficient on option exercises in the share dilution regression should be near one (firm issues or re-issues one share when the option is exercised).

Stock option grants made over the past few years should have predictive power for current period repurchases. Further, one should expect the relationship between stock option grants and share repurchases to change with the age of the grant. Since options are typically granted at-the-money, grants during the current year will usually not have as large a dilutive effect on EPS over the year as would option grants which were granted previously and outstanding the whole year. For example, option grants made at the end of 1998 would have no dilutive effect on 1998 EPS. This implies that share repurchases in the current year should be more strongly correlated with the number of options granted a year ago relative to the number of grants in the current period. Since options typically become exercisable ratably one through four years after the grant date, the fraction of grants made a year ago that are still outstanding will be higher than the fraction of grants made four years ago which are still outstanding. ${ }^{22}$ This observation suggests that share repurchases in the current year should be most strongly associated with the number of options granted a year ago, with the correlation somewhat less with the number of grants made more than a year ago. Some of these older grants are no longer outstanding as they have already been exercised or canceled.

On the other hand, suppose instead that firms do not care how stock option grants will affect EPS. When options are exercised, the firm will receive an influx of cash. If the firm has no good use for this additional cash flow, it may wish to distribute the proceeds from option exercises to shareholders via share repurchases. In this case, repurchases should respond more to option exercises than option grants. This

\footnotetext{
${ }^{21}$ If Earnings / Price equals the return earned on the proceeds received when the option is exercised, then EPS will be unaffected.

${ }^{22}$ This reflects an increased likelihood that an option awarded four years ago will be canceled or exercised relative to an option awarded a year ago. Huddart and Lang (1996) find that exercise activity is strongly associated with the proximity to vesting dates.
} 
implies that the coefficient on option exercises would be substantially less than one, and past option grants should have little explanatory power.

Tables 7 and 8 test these predictions. The dependent variable is the change in outstanding shares during the year divided by the number of common shares outstanding at the beginning of the year, thus a negative value indicates a repurchase of stock. The option variables are all normalized by shares outstanding. I dropped 92 observations in which a large merger or spin-off during the year made option data incompatible with previous years. Observations were dropped when the number of options assumed due to mergers/acquisitions or adjusted due to a spin-off represented five percent of total options (the results are not sensitive to the cutoff point chosen). All the robust regressions include firm-specific and time-specific controls.

Table 7 reveals the two countervailing effects of stock options, as options cause both a repurchase and later issuance/reissuance of shares. ${ }^{23}$ One cannot statistically reject that stock option exercises increase shares outstanding on a one-for-one basis, indicating that firms do not time the repurchase of stock to correspond with option exercises. However, there is evidence that firms partially pre-fund option programs by repurchasing shares. Assuming an option is held on average five years, the coefficient of -.076 on outstanding options implies that a firm repurchases roughly $38 \%$ of the shares underlying an option grant prior to exercise. This is in the ballpark of the $44 \%$ implied by the estimate obtained earlier from the crosssection with a different methodology. Consistent with the earlier results, a higher market-to-book ratio and higher debt are associated with greater share dilution (firms with good investment opportunities and more leverage repurchase less stock or raise funds by issuing more equity).

Table 8 presents further evidence on how firms respond to stock option grants and exercises by including grants during the year and over the past four years in the share dilution/repurchase regression. To be included in the regression a firm must have data on option grants over the previous four years, so the sample size is reduced. Since the 1988 10-K statement will often report option grants from 1986-88, some firms will have data on option grants the past four years starting in 1990. The time series of grants is a highly significant predictor of share repurchases. Firms appear to gradually repurchase shares over the life of an option, as grants made three years ago are still significant predictors of current period share repurchases. The pattern in the option grants coefficient is consistent with the predictions of the undo dilution hypothesis. Option grants made last year are more associated with stock buybacks than are current year option grants. Recall options granted in the current year have been outstanding for only a portion of

${ }^{23}$ OLS estimates are 1.133 (standard error of .266) for option exercises and -.296 (standard error of .105) for options outstanding. A median regression yields coefficients of .993 (standard error of .109) for option exercises and -.096 (standard error of .057) for options outstanding. 
the year, and thus have a limited dilutive effect on EPS during the year. Further, the estimated increase in share repurchases attributable to grants 2-4 years ago tapers off somewhat from the effect of options granted just last year. The coefficient on total outstanding options, once option grants over the current year and previous four years are included in the specification, is small and insignificant. This likely reflects that most of the options granted more than four years ago have already been exercised, and thus do not affect current payout policy. The number of stock option grants made during the current year and the previous four years exceeds options outstanding at the end of the year for $70 \%$ of the firm-year observations.

A few conclusions can be drawn from the analysis in this section. Firms do not simply repurchase shares when options are exercised to distribute the proceeds received from option exercises. Nor do firms repurchase shares on a one-for-one basis to satisfy option exercises. They rather seem to gradually repurchase the amount necessary to undo the dilution that occurs to EPS. For example, the ultimate dilution an option grant will have on EPS is $(\mathrm{P}-\mathrm{X}) / \mathrm{P}$ where $\mathrm{P}$ is the stock price when the option is exercised and $\mathrm{X}$ is the option's exercise price. Over the past five years, both the mean and median ratio of the exercise price of exercised options to the average of the firm's beginning and end of year stock prices have been .52 in the sample. Given annual stock price appreciation of $16 \%$, the sample median, the stock price would grow to twice the exercise price of an option granted at-the-money in 4.4 years. The sum of the coefficients on the option grants made during the current year and the previous four years ranges from -..52 to -.55 across the three specifications in Table 8. Assuming an option is held on average five years, the estimates from the cross-section in Section 4.1 implied that a firm repurchases roughly two fifths of the shares underlying an option grant prior to exercise. Thus, the estimates suggest that the sampled firms repurchase about two-fifths to a half of the shares underlying a stock option grant over a four to five year period. This essentially undoes the dilutive effect a stock option would have on EPS over that same period. $^{24}$ Both the pattern and magnitude of the coefficients in the share dilution/repurchase regressions are consistent with the undo dilution hypothesis. Taking the coefficients from Tables 7 and 8 at face value, the presence of stock option programs has boosted the fraction of shares repurchased by roughly $1 / 2$ percentage point annually for these large firms in the mid to late 1990s. Further, the increase in stock option grants in the nineties has increased the fraction of shares repurchased by an estimated 1/5 percentage point from 1994 to 98 . This accounts for roughly a third of the increase in repurchases over that period.

${ }^{24}$ Firms typically grant both nonqualified and incentive stock options, but they do not report how many of each type were granted. In addition to the exercise proceeds $\mathrm{X}$, the firm also receives a tax benefit of $\tau(\mathrm{P}-\mathrm{X})$ when a nonqualified stock option is exercised (where $\tau$ is the corporate tax rate and $\mathrm{P}$ and $\mathrm{X}$ are the stock price and exercise price, respectively). The firm receives no tax benefit when an incentive stock option is exercised, assuming that the stock is held at least two years after the option is granted and one year after the option is 
One should keep in mind a key caveat when interpreting the results of this section. Any study that uses an extensive panel data set naturally imposes some survivorship bias. The current members of the S\&P 100, Dow Jones Industrials, and S\&P 500 Tech sector have performed better on average over the years and are by definition larger than a random sample of firms. Since these firms also generally have earnings and cash on hand to repurchase stock, the incentive and ability to repurchase shares to undo the dilution from option programs may be greater for this sample than for the corporate sector as a whole.

\section{Conclusion}

The use of stock options has increased steadily in the 1990s. This development could have implications for corporate payout policy. This paper presents evidence that the overall size of a firm's option program and past option grants are strong predictors of subsequent share repurchases. Why are outstanding stock options a strong predictor of future repurchases? Why do option grants seem to cause limited share dilution for large firms? One potential explanation involves earnings per share management. Stock options will ultimately dilute earnings per share (EPS). There is both anecdotal and empirical evidence of the importance placed upon reported earnings per share by investors, financial advisors, and managers, and the reluctance of firms to take on dilutive transactions. Further, some corporations tie annual bonuses to EPS. For some firms, a share repurchase program may undo the erosion to EPS that results from a stock option program, and potentially make it more difficult to observe the cost of stockbased compensation. This paper presents evidence that stock option programs in general are associated with increased stock buybacks and decreased earnings retention. The analysis in this paper also suggests that large firms conduct a gradual repurchase of shares to undo much of the dilution to earnings per share that results from stock option grants.

Since most firms do not dividend-protect their options, top executives may have an incentive to substitute share repurchases and/or earnings retention for dividends to increase the value of their option holdings. Consistent with previous work that found a negative correlation between dividends and executive options, this paper finds that firms whose top executives hold more options retain more earnings over 199596, but finds no evidence that such option-induced dividend reductions have led to increased share repurchases. Thus, I find that stock option grants to top executives affect payout policy differently than do stock option grants to other employees.

exercised. Thus, given the stock price is twice the exercise price, the weight given to an outstanding stock option when calculating the denominator of EPS will be between .325 and .5 , assuming a tax rate of .35 . 
This paper has focused on stock options diluting EPS by increasing the number of shares over which earnings are divided. It is difficult to gauge whether the granting of stock options has at the same time increased the numerator. Stock-based compensation may help better align the incentives of firm employees, particularly upper management, with those of shareholders. This could potentially increase a firm's profitability. In other words, the granting of stock options divides the pie into more pieces, but it may also increase the size of the pie to be divided. Another possibility is that firms have reduced cashbased compensation in response to the granting of stock-based compensation. Since stock options are generally not counted as an expense against reported earnings, but cash wages are, this would have the effect of boosting reported earnings. To the extent that either of these occurs in practice, or is likely to occur in the future, the dilutive effect of stock options on reported EPS would be mitigated. These are two topics for future research.

What are the implications for future trends in corporate policy? While stock options do not result in "dollars out of a company's coffers" when issued, they do ex post in the form of stock buybacks. This could lower funds available to finance future investment, which would affect future cash flows. The increased use of stock options this decade at first glance would suggest share repurchases should continue to grow in the near term, despite rising stock prices. However, rising price-earnings ratios make funding stock option programs with repurchased shares a more costly and perhaps unsustainable strategy. Further, if grant rates level off, some boards cap grants at a certain percentage of shares outstanding, this would suggest that the option-induced boost to share repurchases will level off as well.

Fama and French (1999) examine reasons for the disappearance of dividends. They document a decline in the propensity to pay dividends over time, after controlling for firm characteristics. Crosssectional evidence in this paper suggests that the option-induced repurchase of stock is associated with higher total distributions, rather than being largely offset by reduced dividend payouts. More work needs to be done to test whether the growing use of stock options has contributed to the reduced propensity or need to pay dividends. By aligning the incentives of shareholders and managers, stock options could be viewed as a substitute to dividends as a means of reducing agency problems.

This paper suggests three avenues for further research. First, is the use of stock-based compensation capitalized into share prices? Stock options granted to employees are not realized as an expense against earnings. Further, the dilutive effect of stock options on the denominator of EPS can at least partially be undone with a share repurchase program. Do investors process all the information in financial statements properly, and see through the accounting numbers and possible earnings management, when valuing firms? On the other hand, to the extent that stock-based compensation enhances productivity 
and aligns the incentives of insiders and shareholders, the use of stock options may boost firm value on net. Core, Guay, and Kothari (1999) and Rees and Stott (1998) provide mixed evidence on this issue. Further research into whether option programs are capitalized into equity prices would be fruitful. In a similar vein, Feldstein and Seligman (1981) and Bulow, Morck, and Summers (1987) find that a corporation's unfunded pension liability is capitalized into share prices.

Second, a related question is how should the market view repurchases by firms with a large number of outstanding options? Liang and Sharpe (1999) illustrate that the growing importance of stock options makes incorporating share repurchases into valuation models more complicated. The positive excess return surrounding repurchase announcements has been well documented, and is generally attributed to a signal of undervaluation or a permanent purging of free cash flow. Ikenberry, Lakonishok, and Vermaelen (1995) and Stephens and Weisbach (1998) report that share repurchase announcements and actual repurchases in the U. S. were negatively related to prior stock price performance in the 1980s and early 1990s. However, corporations have been increasingly buying back stock in the strong bull market of the mid to late 1990s. This paper highlights that some firms may simply repurchase stock to counter the dilutive effect of past stock option grants. In this case, the repurchase is not conducted to signal undervaluation or purge free cash flow, and the timing of the repurchase itself may be less sensitive to stock prices. Thus, the relationship between a repurchase program and both prior and post stock price performance should depend upon why the repurchase was conducted. Whether investors account for the different motivations for buying back stock is another question left to future research.

Finally, there is a substantial literature that tests for earnings management by focusing on specific discretionary accruals such as depreciation estimates, loan loss reserves, deferred tax valuation allowances, etc.. Firms also have discretion over the timing of when they repurchase stock. Firms may be able to shift share buyback programs to help meet threshold earnings per share targets. A careful examination of the distribution of stock repurchases around quarters in which firms just match a threshold EPS target could shed some light on whether stock buybacks are used more broadly as an EPS management tool. 


\section{References}

Andrade, Gregor, 1999, "Do Appearances Matter? The Impact of EPS Accretion and Dilution on Stock Prices," Working paper, Harvard Business School.

Asquith, Paul R. and David W. Mullins, 1986, "Signaling with Dividends, Stock Repurchases, and Equity Issues," Financial Management 15, 27-44.

Bagwell, Laurie S., 1991, "Share Repurchase and Takeover Deterrence," RAND Journal of Economics 22, 72-88.

Bagwell, Laurie S. and John B. Shoven, 1988, "Share Repurchases and Acquisitions: An Analysis of Which Firms Participate," in Corporate Takeovers: Causes and Consequences (Chicago, IL: University of Chicago Press), 191-213.

Barth, M., J. Elliot, and M. Finn, 1995, "Market Rewards Associated with Increasing Earnings Patterns," Working paper, Cornell University.

Berger, Philip G., Eli Ofek, and David Yermack, 1997, "Managerial Entenchment and Capital Structure Decisions," Journal of Finance 52, 1411-1438.

Bulow, Jeremy I., Randall Morck, and Lawrence Summers, 1987, "How Does the Market Value Unfunded Pension Liabilities?," in Z. Bodie, J. Shoven, and D. Wise ed., Issues in Pension Economics, (Chicago, IL: University of Chicago Press), 81-104.

Burgstahler, David and Ilia Dichev, 1997, "Earnings Management to Avoid Earnings Decreases and Losses," Journal of Accounting and Economics 24, 99-126.

Comment, Robert and Gregg Jarrell, 1991, "The Relative Signaling Power of Dutch-Auction and Fixed Price Self-Tender Offers and Open-Market Share Repurchases," Journal of Finance 46, 1243-1271.

Cook, Douglas, Laurie Krigman, and J. Chris Leach, 1997a, "Safe Harbor or Smoke Screen? Compliance and Disclosure Under SEC Rule 10b-18," Working paper, University of Arizona.

Cook, Douglas, Laurie Krigman, and J. Chris Leach, 1997b, "Corporate Repurchase Programs: Execution Strategy and the Competing Market-maker Effect," Working paper, University of Arizona.

Core, John, Wayne Guay, and S. P. Kothari, 1999, "SFAS No. 128 Diluted EPS Fails to Capture the Economic Dilution of Employee Stock Options," Working paper, University of Pennsylvania and MIT.

Dann, Larry, 1981, "The Effects of Common Stock Repurchase on Security Holders' Returns," Journal of Financial Economics 9, 101-138.

DeAngelo, Harry, Linda DeAngelo, and Douglas Skinner, 1996, "Reversal of Fortune: Dividend Signaling and the Disappearance of Sustained Earnings Growth," Journal of Financial Economics 40, 341-371. 
Degeorge, Francois, Jayendu Patel, and Richard Zeckhauser, 1999, "Earnings Management to Exceed Thresholds," Journal of Business, 72, 1-33.

Denis, David J., 1990, "Defensive Changes in Corporate Payout Policy: Share Repurchases and Special Dividends," Journal of Finance 45, 1433-1456.

Dhaliwal, Dan S., Merle Erickson, and Robert Trezevant, 1999, "A Test of the Theory of Tax Clientels for Dividend Policies," National Tax Journal 52(2), 179-194.

Dickson, Joel M. and John B. Shoven, 1995, "Taxation and Mutual Funds: An Investor Perspective," in J. Poterba, ed., Tax Policy and the Economy, Volume 9 (Cambridge, MA: MIT Press), 151-180.

Erickson, Merle and Shiing-wu Wang, 1999, "Earnings Management by Acquiring Firms in Stock for Stock Mergers," Journal of Accounting and Economics 27(2), 149-176.

Fama, Eugene, and Kenneth R. French, 1999, "Disappearing Dividends: Changing Firm Characteristics or Lower Propensity to Pay," The Center for Research in Security Prices Working Paper No. 509.

Feldstein, Martin and Stephanie Seligman, 1981, "Pension Funding, Share Prices, and National Savings," Journal of Finance 36, 801-824.

Fenn, George W. and Nellie Liang, 2000, "Corporate Payout Policy and Managerial Stock Incentives," Journal of Financial Economics, forthcoming.

Grullon, Gustavo, and Roni Michaely, 2000, "Dividends, Share Repurchases, and the Substitution Hypothesis," Working Paper, Rice University and Cornell University.

Guay, Wayne and Jarrad Harford, 2000, "The Cash Flow Permanence and Information Content of Dividend Increases vs. Repurchases," Journal of Financial Economics, forthcoming.

Guidry, Flora, Andrew J. Leone, and Steve Rock, 1999, "Earnings-based Bonus Plans and Earnings Management by Business-Unit Managers," Journal of Accounting and Economics 26, 113-142.

Hall, Brian J. and Jeffrey B. Liebman, 1998, “Are CEOs Really Paid Like Bureaucrats?, Quarterly Journal of Economics 111(3), 653-691.

Hamilton, L. C., 1991, “How Robust is Robust Regression?,” Stata Technical Bulletin, 2, 21-26.

Healy, Paul M., 1985, "The Effect of Bonus Schemes on Accounting Decisions," Journal of Accounting and Economics 7, 85-107.

Holthausen, Robert W., David F. Larker, and Richard G. Sloan, 1995, "Annual Bonus Schemes and the Manipulation of Earnings," Journal of Accounting and Economics 19, 29-74.

Huddart, Steven, and Mark Lang, 1996, "Employee Stock Option Exercises An Empirical Analysis, Journal of Accounting and Economics 21, 5-43.

Ikenberry, David, Joseph Lakonishok, and Theo Vermaelen, 1995, "Market Underreaction to Open Market Share Repurchases," Journal of Financial Economics 39, 181-208. 
Jagannathan, Murali, Clifford P. Stephens, and Michael S. Weisbach, 2000, "Financial Flexibility and the Choice Between Dividends and Stock Repurchases," Journal of Financial Economics, forthcoming.

Jensen, Michael, 1986, “Agency Costs of Free Cash Flow, Corporate Finance, and Takeovers," American Economic Review 76, 323-329.

Jolls, Christine, 1998, "Stock Repurchases and Incentive Compensation," NBER working paper No. 6467 (Cambridge, MA: National Bureau of Economic Research).

Lambert, Richard A., William N. Lanen, and David F. Larcker, 1989, "Executive Stock Option Plans and Corporate Dividend Policy," Journal of Financial and Quantitative Analysis 24, 409-425.

Liang, Nellie, and Steven A. Sharpe, 1999, "Share Repurchases and Employee Stock Options and their Implications for S\&P 500 Share Retirements and Expected Returns," FEDS working paper 1999-59.

Matsunaga, Steven R., 1995, "The Effects of Financial Reporting Costs on the Use of Employee Stock Options," The Accounting Review 70, 1-26.

Mehran, Hamid, George E. Nogler, and Kenneth B. Schwartz, 1998, "CEO Incentive Plans and Corporate Liquidation," Journal of Financial Economics 50, 319-349

Murphy, Kevin, 1998, "Executive Compensation," in Orley Ashenfelter and David Card, eds., Handbook of Labor Economics, Volume 3 (Amsterdam: North-Holland).

Nohel, Tom, and Vefa Tarhan, 1998, "Share Repurchases and Firm Performance: New Evidence on the Agency Costs of Free Cash Flow,” Journal of Financial Economics 49, 187-222.

Poterba, James M. and Lawrence H. Summers, 1985, “The Economic Effects of Dividend Taxation,” in E. Altman and M. Subrahmanyam, Recent Advances in Corporation Finance (Homewood, IL: Richard D. Irwin), 227-284.

Rangan, Srinivasan, 1998, "Earnings Management and the Performance of Seasoned Equity Offerings," Journal of Financial Economics 50, 101-122.

Rees, Lynn, and David Stott, 1998, "The Value-Relevance of Stock-Based Employee Compensation Disclosures," Working paper, Texas A \& M and Washington State University.

Stephens, Clifford P. and Michael S. Weisbach, 1998, "Actual Share Reacquisitions in Open-Market Repurchase Programs," Journal of Finance 53, 313-333.

Street, James O., Raymond J. Carroll, and David Ruppert, 1988, “A Note on Computing Robust Regression Estimates via Iteratively Reweighted Least Squares," The American Statistician 42, 152-154.

Teoh, Siew Hong, Ivo Welch, and T. J. Wong, 1998a, "Earnings Management and the Underperformance of Seasoned Equity Offerings," Journal of Financial Economics 50, 63-69.

Teoh, Siew Hong, Ivo Welch, and T. J. Wong, 1998b, "Earnings Management and the Long-run Performance of Initial Public Offerings," Journal of Finance 53, 1935-1974. 
Usem, M. J., D. Schulman, and J. F. Brown, 1995, "Share Repurchases 1994-Real or Imagined?," Working paper, Salomon Brothers.

Vermaelen, Theo, 1981, "Common Stock Repurchases and Market Signaling: An Empirical Study," Journal of Financial Economics 9, 139-183.

Wasserstein, Bruce, 1998, Big Deal: The Battle for Control of America's Leading Corporations (New York: Warner Books). 


\begin{tabular}{|c|c|c|c|c|}
\hline & \multicolumn{4}{|c|}{ Stock Option Overhang as a percent of Shares Outstanding } \\
\hline & \multicolumn{2}{|c|}{ Unweighted } & \multicolumn{2}{|c|}{ Weighted by market value } \\
\hline & Median & $90^{\text {th }}$ percentile & Median & $90^{\text {th }}$ percentile \\
\hline 1985 & $4.51 \%$ & $11.49 \%$ & $3.03 \%$ & $8.12 \%$ \\
\hline 1986 & 4.67 & 12.03 & 3.02 & 8.66 \\
\hline 1987 & 4.59 & 12.21 & 3.77 & 8.92 \\
\hline 1988 & 4.79 & 13.10 & 3.60 & 8.45 \\
\hline 1989 & 5.06 & 14.30 & 3.53 & 8.52 \\
\hline 1990 & 5.38 & 14.79 & 3.46 & 9.41 \\
\hline 1991 & 5.75 & 16.24 & 3.70 & 8.85 \\
\hline 1992 & 5.75 & 16.39 & 4.06 & 10.15 \\
\hline 1993 & 5.62 & 16.02 & 4.22 & 10.34 \\
\hline 1994 & 5.97 & 15.51 & 4.49 & 11.79 \\
\hline 1995 & 6.50 & 16.39 & 4.69 & 11.54 \\
\hline 1996 & 7.20 & 16.08 & 5.35 & 12.39 \\
\hline
\end{tabular}

The stock option overhang refers to shares reserved for options (annual data item 215 in Compustat) at the beginning of the year. This measures options currently outstanding and those available for future grants. Weighted statistics are weighted by firm market capitalization.

"Shares reserved for options" overstates outstanding options, which Compustat does not report, since it also includes the number of shares available for future grants under existing board approved plans. 
Table 2: Dilution from Stock Option Programs at end of 1998

How much do dilutive securities reduce earnings per share

for firms with EPS $>0$ in fiscal year 1998?

(percent reduction in EPS)

\begin{tabular}{|c|c|c|c|c|}
\hline & $\begin{array}{c}\text { Average reduction } \\
\text { for firms in group }\end{array}$ & $\begin{array}{c}\text { Reduction for } \\
\text { group as a whole }\end{array}$ & $\begin{array}{c}\text { Fraction of firms } \\
\text { with }>5 \% \\
\text { reduction }\end{array}$ & $\begin{array}{c}\text { Fraction of firms } \\
\text { with }>10 \% \\
\text { reduction }\end{array}$ \\
\hline S\&P 1500 & $2.5 \%$ & $2.2 \%$ & $12.8 \%$ & $2.8 \%$ \\
\hline Mid/Small Caps & 2.6 & 2.7 & 15.2 & 3.3 \\
\hline S\&P 500 & 2.1 & 2.2 & 8.1 & 1.9 \\
\hline S\&P 500 Tech & 4.2 & 4.4 & 27.7 & 8.5 \\
\hline
\end{tabular}

The reduction to EPS due to outstanding dilutive securities presented in the upper panel is simply one less the ratio of diluted EPS to basic EPS. 


\begin{tabular}{|c|c|c|c|}
\hline \multicolumn{4}{|c|}{$\begin{array}{l}\text { Table 3: Summary Statistics for Option Programs and Distributions } \\
\text { for S\&P 500, MidCap 400, and Forbes } 500 \text { firms at end of } 1994\end{array}$} \\
\hline & $\begin{array}{c}\text { Mean \& } \\
\text { Standard Deviation }\end{array}$ & Median & $10^{\text {th }}-90^{\text {th }}$ percentile \\
\hline $\begin{array}{c}\text { Total Options } \\
\text { Outstanding normalized } \\
\text { by shares outstanding } \\
\text { end of } 94\end{array}$ & $\begin{array}{l}.057 \\
(.047)\end{array}$ & .046 & $.013-.115$ \\
\hline $\begin{array}{c}\text { CEO Options } \\
\text { Outstanding normalized } \\
\text { by shares outstanding } \\
\text { end of } 94\end{array}$ & $\begin{array}{l}.007 \\
(.011)\end{array}$ & .004 & $.000-.016$ \\
\hline $\begin{array}{l}\text { CEO Options / } \\
\text { Total Options }\end{array}$ & $\begin{array}{l}.124 \\
(.116)\end{array}$ & .091 & $.018-.256$ \\
\hline $\begin{array}{c}\text { Top } 5 \text { Executives } \\
\text { Options Outstanding } \\
\text { normalized by shares } \\
\text { outstanding end of } 94\end{array}$ & $\begin{array}{l}.016 \\
(.018)\end{array}$ & .011 & $.002-.035$ \\
\hline $\begin{array}{c}\text { Top } 5 \text { Options / } \\
\text { Total Options }\end{array}$ & $\begin{array}{c}.278 \\
(.180)\end{array}$ & .237 & $.080-.530$ \\
\hline $\begin{array}{c}\text { Direct Individual } \\
\text { Ownership end of } 94\end{array}$ & $\begin{array}{l}.38 \\
(.19)\end{array}$ & .36 & $.16-.64$ \\
\hline $\begin{array}{l}\text { Prob(Repurchase }>0) \\
\text { in } 1995 \\
\end{array}$ & $\begin{array}{l}.50 \\
(.50) \\
\end{array}$ & & \\
\hline $\begin{array}{c}\text { Prob(Repurchase }> \\
.01 * \text { Market Value) }\end{array}$ & $\begin{array}{l}.29 \\
(.45)\end{array}$ & & \\
\hline $\begin{array}{c}\text { REPURCHASES } \\
\text { in } 1995 / \\
\text { MARKET VALUE }\end{array}$ & $\begin{array}{l}.014 \\
(.030)\end{array}$ & 0 & $0-.041$ \\
\hline $\begin{array}{l}\text { Prob(DIVIDEND > 0) } \\
\text { in } 1995\end{array}$ & $\begin{array}{l}.75 \\
(.43)\end{array}$ & & \\
\hline $\begin{array}{l}\text { DIVIDENDS in } 95 \text { / } \\
\text { MARKET VALUE }\end{array}$ & $\begin{array}{c}.017 \\
(.014)\end{array}$ & .016 & $0-.036$ \\
\hline $\begin{array}{l}\text { TOTAL PAYOUT / } \\
\text { MARKET VALUE }\end{array}$ & $\begin{array}{l}.030 \\
(.035)\end{array}$ & .024 & $0-.065$ \\
\hline $\begin{array}{c}\text { REPURCHASES / } \\
\text { (Total Cash Payouts) in } \\
1995\end{array}$ & $\begin{array}{l}.31 \\
(.35)\end{array}$ & .15 & $0-.90$ \\
\hline
\end{tabular}

The sample consists of non-bank and non-utility members of the S\&P 500, MidCap 400, and/or Forbes 500 at the end of fiscal year 1994 (826 firms). Data on total outstanding options were obtained from 10Ks or annual reports. Executive option holdings were obtained from proxy statements.

MARKET VALUE is the average of a firm's market value at the beginning and end of 1995. 


\begin{tabular}{|c|c|c|c|c|c|}
\hline \multicolumn{6}{|c|}{$\begin{array}{l}\text { Table 4: Regressions of Share Repurchases and Total Payouts } \\
\text { Coefficients from Tobit model in columns (1) - (5) }\end{array}$} \\
\hline & (1) & (2) & (3) & (4) & (5) \\
\hline & \multicolumn{3}{|c|}{$\begin{array}{c}\text { Dependent Variable }= \\
\text { REPURCHASES in } 95 / \text { MARKET VALUE }\end{array}$} & \multicolumn{2}{|c|}{$\begin{array}{l}\text { Dep. Variable = } \\
\text { TOTAL PAYOUT in } 95 / \\
\text { MARKET VALUE }\end{array}$} \\
\hline $\begin{array}{c}\text { Total } \\
\text { Outstanding } \\
\text { Options / } \\
\text { Shares } \\
\text { Outstanding }\end{array}$ & $\begin{array}{l}.200 * * \\
(.048)\end{array}$ & & $\begin{array}{l}.205^{* *} \\
(.062)\end{array}$ & $\begin{array}{l}.082 * * \\
(.035)\end{array}$ & $\begin{array}{l}.093 * \\
(.046)\end{array}$ \\
\hline $\begin{array}{c}\text { Top 5 } \\
\text { Executives } \\
\text { Options / } \\
\text { Shares } \\
\text { Outstanding }\end{array}$ & & $\begin{array}{l}.326 * * \\
(.127)\end{array}$ & $\begin{array}{l}-.020 \\
(.165)\end{array}$ & & $\begin{array}{l}-.046 \\
(.100)\end{array}$ \\
\hline $\begin{array}{l}\text { Individual } \\
\text { Ownership } \\
\text { of Firm }\end{array}$ & $\begin{array}{l}-.001 \\
(.012)\end{array}$ & $\begin{array}{l}-.004 \\
(.012)\end{array}$ & $\begin{array}{l}-.001 \\
(.012)\end{array}$ & $\begin{array}{c}.003 \\
(.008)\end{array}$ & $\begin{array}{c}.003 \\
(.008)\end{array}$ \\
\hline $\begin{array}{c}\text { Capital } \\
\text { Expenditures }\end{array}$ & $\begin{array}{l}-.051 \\
(.054)\end{array}$ & $\begin{array}{l}-.034 \\
(.054)\end{array}$ & $\begin{array}{l}-.051 \\
(.054)\end{array}$ & $\begin{array}{l}-.060^{*} \\
(.035)\end{array}$ & $\begin{array}{l}-.060^{*} \\
(.035)\end{array}$ \\
\hline $\begin{array}{l}\text { Operating } \\
\text { Income }\end{array}$ & $\begin{array}{l}.227 * * \\
(.041)\end{array}$ & $\begin{array}{l}.209 * * \\
(.041)\end{array}$ & $\begin{array}{l}.227 * * \\
(.041)\end{array}$ & $\begin{array}{l}.189 * * \\
(.029)\end{array}$ & $\begin{array}{l}.189 * * \\
(.029)\end{array}$ \\
\hline $\begin{array}{l}\text { Non-Operating } \\
\text { Income }\end{array}$ & $\begin{array}{l}.728 * * \\
(.196)\end{array}$ & $\begin{array}{l}.755^{* *} \\
(.196)\end{array}$ & $\begin{array}{l}.728 * * \\
(.196)\end{array}$ & $\begin{array}{l}.413 * * \\
(.128)\end{array}$ & $\begin{array}{l}.412 * * \\
(.128)\end{array}$ \\
\hline $\begin{array}{l}\text { Market-to-book } \\
\text { ratio }\end{array}$ & $\begin{array}{c}-.015^{* *} \\
(.004)\end{array}$ & $\begin{array}{c}-.014 * * \\
(.004)\end{array}$ & $\begin{array}{c}-.015^{* *} \\
(.004)\end{array}$ & $\begin{array}{c}-.016^{* * *} \\
(.003)\end{array}$ & $\begin{array}{l}-.016^{* * *} \\
(.003)\end{array}$ \\
\hline $\begin{array}{l}\text { Long-term } \\
\text { Debt end of } 94\end{array}$ & $\begin{array}{c}-.059 * * \\
(.017)\end{array}$ & $\begin{array}{c}-.056^{* *} \\
(.016)\end{array}$ & $\begin{array}{c}-.059 * * \\
(.017)\end{array}$ & $\begin{array}{c}-.055^{* *} \\
(.011)\end{array}$ & $\begin{array}{c}-.055^{* *} \\
(.011)\end{array}$ \\
\hline $\begin{array}{l}\text { Return } \\
\text { in } 1994\end{array}$ & $\begin{array}{c}.003 \\
(.008)\end{array}$ & $\begin{array}{c}.002 \\
(.008)\end{array}$ & $\begin{array}{c}.003 \\
(.008)\end{array}$ & $\begin{array}{l}-.004 \\
(.005)\end{array}$ & $\begin{array}{l}-.004 \\
(.005)\end{array}$ \\
\hline $\begin{array}{l}\text { Log(Assets in } \\
\text { millions of \$) }\end{array}$ & $\begin{array}{l}.006^{* *} \\
(.002)\end{array}$ & $\begin{array}{l}.006^{* *} \\
(.002)\end{array}$ & $\begin{array}{l}.006^{* * *} \\
(.002)\end{array}$ & $\begin{array}{l}.006^{* *} \\
(.001)\end{array}$ & $\begin{array}{l}.006^{* *} \\
(.001)\end{array}$ \\
\hline $\begin{array}{l}\text { Industry } \\
\text { Controls }\end{array}$ & Yes & Yes & Yes & Yes & Yes \\
\hline Log Likelihood & 554.6 & 549.2 & 554.6 & 1195.0 & 1195.1 \\
\hline Sample Size & 783 & 783 & 783 & 783 & 783 \\
\hline
\end{tabular}

See text and Appendix for variable descriptions. The sample consists of non-bank and non-utility members of the S\&P 500, MidCap 400, and/or Forbes 500 at the end of fiscal year 1994 (826 firms). Forty-three of the 826 observations are lost with the inclusion of the non-option covariates.

Capital expenditures, operating income, non-operating income, and long-term debt are measured during 1994 and are normalized by total assets at the end 1994. The option variables, individual ownership, market-to-book ratio, and the book value of assets are all measured at the end of 1994. Share repurchases during 1995 are normalized by the average of firm value at the beginning and end of 1995. The total payout is the sum of share repurchases and dividends on common stock. Evaluated at the means of the covariates, the scaling factor to convert coefficients to marginal effects in the Tobit model is .43 for the repurchase regressions and .73 for the total payout regressions. Standard errors are reported in parentheses.

$* *=$ coefficient estimate is significant at .05 level, $*=$ coefficient is significant at .10 level 


\begin{tabular}{|c|c|c|c|}
\hline \multicolumn{4}{|c|}{$\begin{array}{c}\text { Table 5: Regression of Retention Rate of Earnings over 1995-96 } \\
\text { Dependent Variable }=1-(\text { Dividends and Repurchases in 1995-96) /(Earnings in 1995-96) }\end{array}$} \\
\hline \multicolumn{4}{|c|}{ Estimated by Robust Regression } \\
\hline $\begin{array}{l}\text { Total Outstanding } \\
\text { Options / } \\
\text { Shares Outstanding }\end{array}$ & $\begin{array}{l}-.177 \\
(.388)\end{array}$ & $\begin{array}{c}-1.007 * \\
(.530)\end{array}$ & $\begin{array}{c}-1.019 * \\
(.527)\end{array}$ \\
\hline $\begin{array}{l}\text { Top } 5 \text { Executive } \\
\text { Options / } \\
\text { Shares Outstanding }\end{array}$ & & $\begin{array}{c}2.710 * * \\
(1.257)\end{array}$ & $\begin{array}{c}2.662 \\
(1.672)\end{array}$ \\
\hline $\begin{array}{l}\text { Executive Options * } \\
\text { (Is market-to-book > } \\
\text { sample median?) }\end{array}$ & & & $\begin{array}{c}.399 \\
(1.639)\end{array}$ \\
\hline $\begin{array}{l}\text { Executive Options * } \\
\quad \text { (Is firm size > } \\
\text { sample median?) }\end{array}$ & & & $\begin{array}{c}-.157 \\
(1.671)\end{array}$ \\
\hline $\begin{array}{l}\text { Individual Ownership } \\
\text { of Firm }\end{array}$ & $\begin{array}{l}-.084 \\
(.084)\end{array}$ & $\begin{array}{l}-.095 \\
(.085)\end{array}$ & $\begin{array}{l}-.095 \\
(.084)\end{array}$ \\
\hline Market-to-book ratio & $\begin{array}{c}.033 \\
(.021)\end{array}$ & $\begin{array}{l}.039 * \\
(.021)\end{array}$ & $\begin{array}{l}.038 * \\
(.022)\end{array}$ \\
\hline $\begin{array}{l}\text { Long-term Debt } \\
\text { at end of } 1994\end{array}$ & $\begin{array}{l}.407 * * \\
(.116)\end{array}$ & $\begin{array}{l}.411^{* *} \\
(.117)\end{array}$ & $\begin{array}{l}.405^{* *} \\
(.116)\end{array}$ \\
\hline $\begin{array}{c}\text { Return } \\
\text { in } 1994\end{array}$ & $\begin{array}{l}.010 \\
(.057)\end{array}$ & $\begin{array}{c}.008 \\
(.057)\end{array}$ & $\begin{array}{c}.008 \\
(.057)\end{array}$ \\
\hline $\begin{array}{c}\log \\
\text { (Assets in \$millions) }\end{array}$ & $\begin{array}{c}-.061 * * \\
(.012)\end{array}$ & $\begin{array}{c}-.052 * * \\
(.013)\end{array}$ & $\begin{array}{c}-.051 * * \\
(.014)\end{array}$ \\
\hline Industry Controls & Yes & Yes & Yes \\
\hline Sample Size & 682 & 682 & 682 \\
\hline
\end{tabular}

The sample consists of non-bank and non-utility members of the S\&P 500, MidCap 400, and/or Forbes 500 at the end of fiscal year 1994.

"Earnings" is income before extraordinary items available for common (annual data item 237 in Compustat). Firms with negative earnings over the two-year period are excluded.

See the text and Appendix for variable descriptions.

Debt is normalized by total assets at the end of 1994. The option variables, individual ownership, marketto-book ratio, and firm size (total assets) are measured at the end of 1994.

Standard errors are reported in parentheses.

$* *=$ coefficient estimate is significant at .05 level, $*=$ coefficient is significant at .10 level 


\begin{tabular}{|c|c|c|c|}
\hline \multicolumn{4}{|c|}{$\begin{array}{l}\text { Table 6: Summary Statistics for Option Programs and Distributions } \\
\text { S\&P 100, Dow Jones Industrials, and S\&P 500 Tech Firms 1990-98 }\end{array}$} \\
\hline & $\begin{array}{c}\text { Mean \& } \\
\text { Standard Deviation }\end{array}$ & Median & $10^{\text {th }}-90^{\text {th }}$ percentile \\
\hline $\begin{array}{c}\text { Stock Option Grants } \\
\text { normalized by shares } \\
\text { outstanding }\end{array}$ & $\begin{array}{l}.019 \\
(.023)\end{array}$ & .012 & $.003-.043$ \\
\hline $\begin{array}{c}\text { Change in } \\
\text { Option Grants } \\
\text { normalized by shares } \\
\text { outstanding 1990-98 }\end{array}$ & $\begin{array}{l}.005 \\
(.028)\end{array}$ & .004 & $-.010-.020$ \\
\hline $\begin{array}{c}\text { Stock Option Exercises } \\
\text { normalized by shares } \\
\text { outstanding }\end{array}$ & $\begin{array}{l}.011 \\
(.012)\end{array}$ & .006 & $.000-.026$ \\
\hline $\begin{array}{c}\text { Change in } \\
\text { Options Exercises } \\
\text { normalized by shares } \\
\text { outstanding 1990-98 }\end{array}$ & $\begin{array}{c}.004 \\
(.011)\end{array}$ & .004 & $-.006-.015$ \\
\hline $\begin{array}{c}\text { Options Outstanding } \\
\text { normalized by shares } \\
\text { outstanding }\end{array}$ & $\begin{array}{l}.065 \\
(.052)\end{array}$ & .051 & $.016-.131$ \\
\hline $\begin{array}{c}\text { Change in } \\
\text { Options Outstanding } \\
\text { normalized by shares } \\
\text { outstanding 1990-98 }\end{array}$ & $\begin{array}{l}.018 \\
(.044)\end{array}$ & .015 & $-.022-.061$ \\
\hline Prob(Repurchase $>0$ ) & $\begin{array}{c}.61 \\
(.49)\end{array}$ & & \\
\hline $\begin{array}{l}\text { REPURCHASES / } \\
\text { MARKET VALUE }\end{array}$ & $\begin{array}{l}.017 \\
(.031)\end{array}$ & .004 & $0-.047$ \\
\hline $\begin{array}{c}\text { Change in Shares } \\
\text { Outstanding / } \\
\text { shares beginning of year }\end{array}$ & $\begin{array}{l}.013 \\
(.067)\end{array}$ & .004 & $-.028-.054$ \\
\hline
\end{tabular}

Sample consists of the 144 current (as of July 1999) non-bank S\&P 100, Dow Jones Industrials, or S\&P 500 Technology firms from 1990-1998. Data on total option programs were obtained from 10-Ks or annual reports. Total of 1089 firm-year observations. 


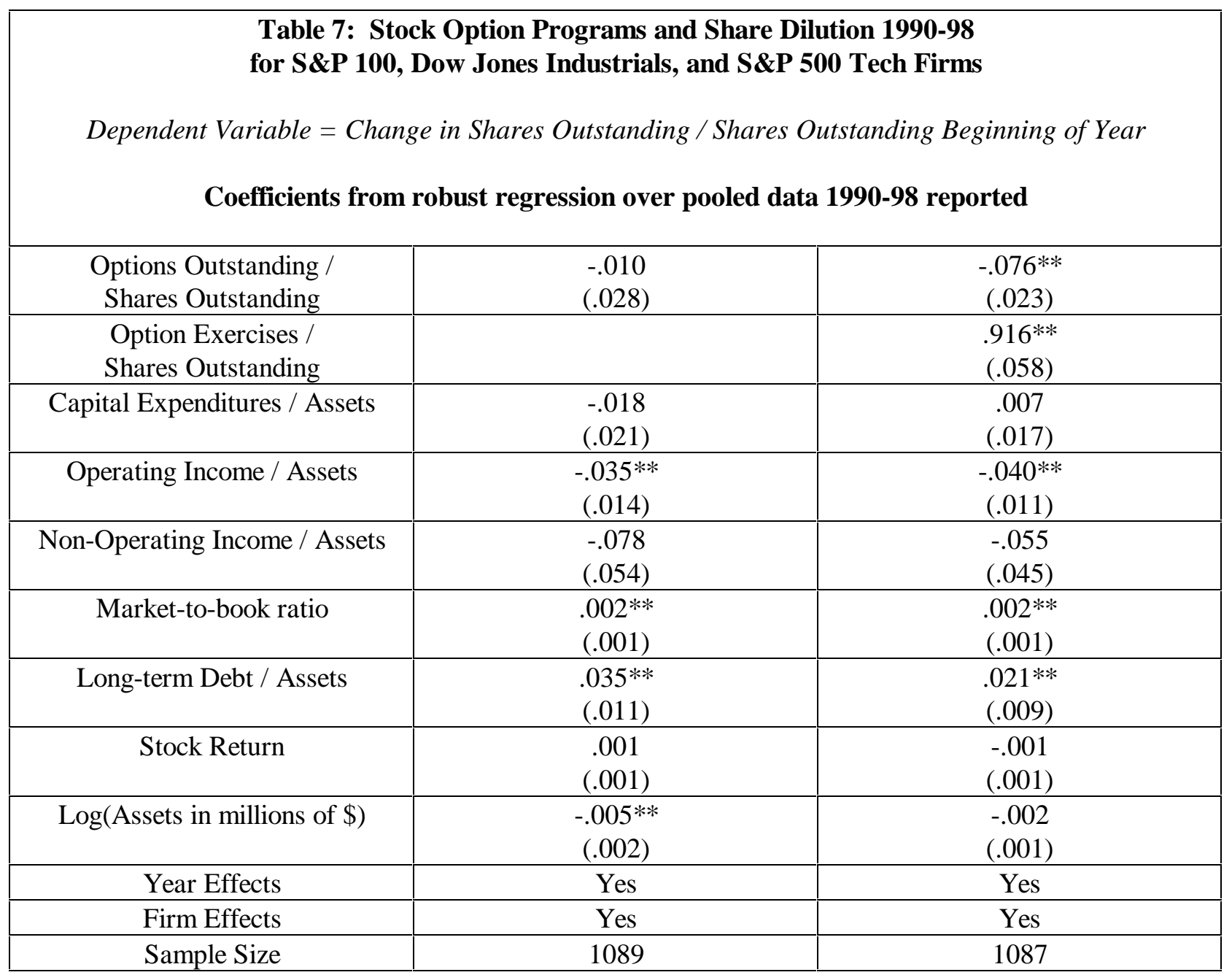

Sample consists of the 144 current non-bank S\&P 100, Dow Jones Industrials, or S\&P 500 Technology firms from 1990-1998. Capital expenditures, income, debt, and the stock return are measured at year t-1. Market-to-book ratio and total assets are measured at the end of year t-1.

Standard errors are reported in parentheses.

$* *=$ coefficient estimate is significant at .05 level, $*=$ coefficient is significant at .10 level 


\begin{tabular}{|c|c|c|c|}
\hline \multicolumn{4}{|c|}{$\begin{array}{l}\text { Table 8: Stock Option Grants and Share Dilution 1990-98 } \\
\text { for S\&P 100, Dow Jones Industrials, and S\&P 500 Tech Firms } \\
\text { It Variable = Change in Shares Outstanding / Shares Outstanding Beginning of Year } \\
\text { Coefficients from robust regression over pooled data 1990-98 reported }\end{array}$} \\
\hline & (1) & $(2)$ & (3) \\
\hline $\begin{array}{l}\text { Option Exercises } \\
\text { in current year }\end{array}$ & $\begin{array}{l}.998 * * \\
(.067)\end{array}$ & $\begin{array}{l}.993 * * \\
(.065)\end{array}$ & $\begin{array}{l}.977 * * \\
(.064)\end{array}$ \\
\hline $\begin{array}{l}\text { Options Outstanding } \\
\text { at end of current year }\end{array}$ & $\begin{array}{l}-.009 \\
(.041)\end{array}$ & & \\
\hline Option Grants in current year & $\begin{array}{l}.084 * * \\
(.041)\end{array}$ & $\begin{array}{l}.092 * * \\
(.029)\end{array}$ & $\begin{array}{l}.093 * * \\
(.029)\end{array}$ \\
\hline Option Grants in year t-1 & $\begin{array}{c}-.214 * * \\
(.042)\end{array}$ & $\begin{array}{c}-.205^{* *} \\
(.034)\end{array}$ & $\begin{array}{c}-.191 * * \\
(.033)\end{array}$ \\
\hline Option Grants in year $\mathrm{t}-2$ & $\begin{array}{l}-.093 * * \\
(.037)\end{array}$ & $\begin{array}{l}.092 * * \\
(.032)\end{array}$ & $\begin{array}{l}-.091 * * \\
(.032)\end{array}$ \\
\hline Option Grants in year $\mathrm{t}-3$ & $\begin{array}{c}-.104 * * \\
(.036)\end{array}$ & $\begin{array}{c}-.107 * * \\
(.034)\end{array}$ & $\begin{array}{c}-.088^{* *} \\
(.034)\end{array}$ \\
\hline Option Grants in year $\mathrm{t}-4$ & $\begin{array}{l}-.051 \\
(.037) \\
\end{array}$ & $\begin{array}{l}-.057 * \\
(.034) \\
\end{array}$ & $\begin{array}{c}-.056^{*} \\
(.034) \\
\end{array}$ \\
\hline Other Financial Covariates & Yes & Yes & No \\
\hline Year Effects & Yes & Yes & Yes \\
\hline Firm Effects & Yes & Yes & Yes \\
\hline Sample Size & 874 & 874 & 876 \\
\hline Sum of grant coefficients & $\begin{array}{c}.546^{* *} \\
(.131)\end{array}$ & $\begin{array}{c}-.554 * * \\
(.088)\end{array}$ & $\begin{array}{c}-.519 * * \\
(.085)\end{array}$ \\
\hline
\end{tabular}

Sample consists of the 144 current non-bank S\&P 100, Dow Jones Industrials, or S\&P 500 Technology firms from 1990-1998. Capital expenditures, operating and non-operating income, market-to-book ratio, debt, the stock-return, and firm size (book value of total assets) are the other financial covariates. The option variables are all normalized by shares outstanding. Standard errors are reported in parentheses. $* *=$ coefficient estimate is significant at .05 level, $*=$ coefficient is significant at .10 level 
Figure 1: Distribution of Option Programs at end of 1994
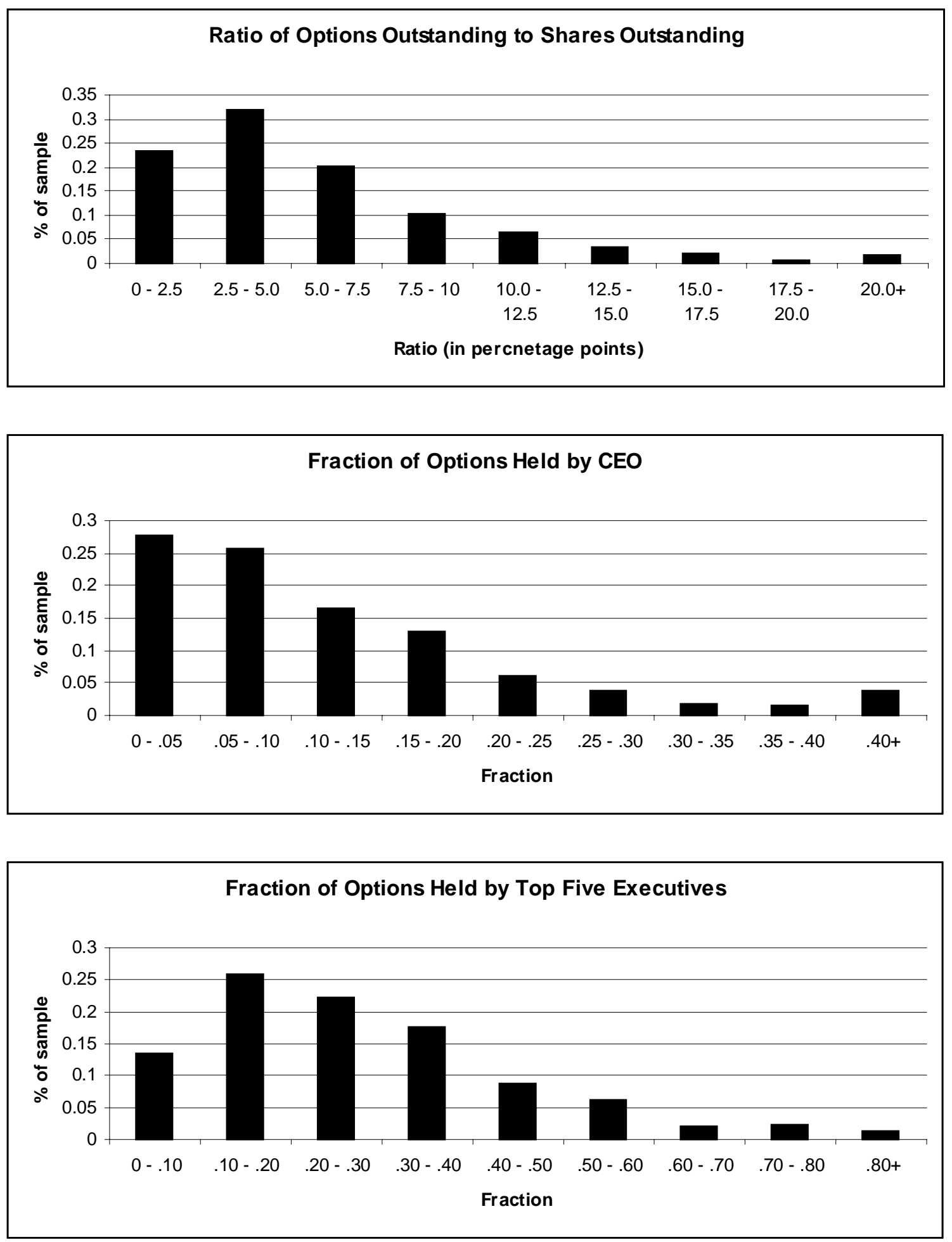

The sample consists of non-bank and non-utility members of the S\&P 500, MidCap 400, and/or Forbes 500 at the end of 1994. Data on total outstanding options were obtained from 10-Ks or annual reports. Executive option holdings were obtained from proxy statements. 
Figure 2: Option Programs and Share Repurchases 1990-98
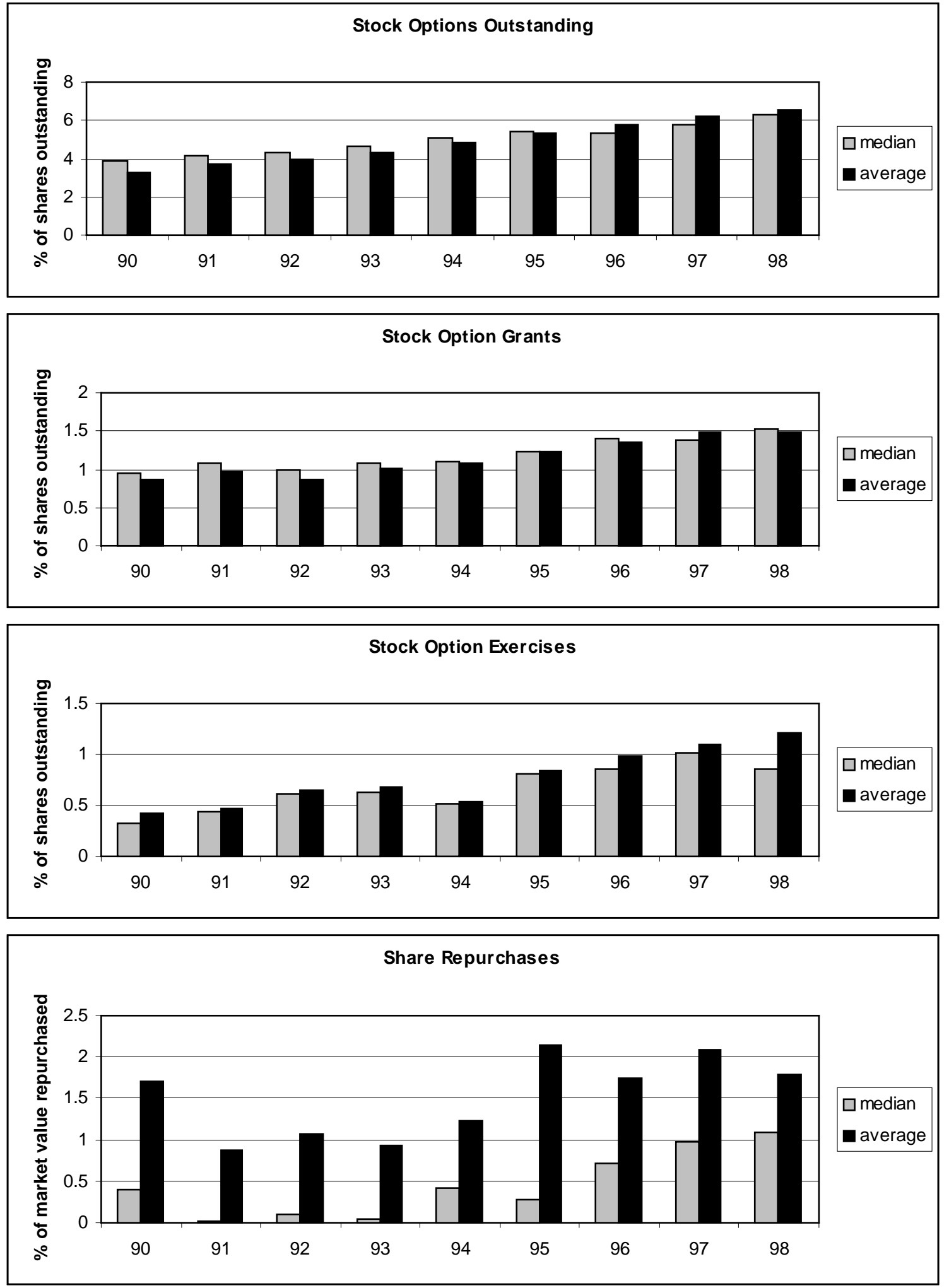

Note: Sample consists of current S\&P 100, Dow Jones Industrials, and S\&P 500 Tech firms that have been in existence and have complete option data from 1990-98 (127 firms). The reported averages are weighted by the average of beginning and end of period firm market value. 


\section{Appendix}

\begin{tabular}{|c|c|c|c|}
\hline \multicolumn{4}{|c|}{ Other Characteristics of S\&P 500, MidCap 400, and Forbes 500 firms at end of 1994} \\
\hline & $\begin{array}{c}\text { Mean \& } \\
\text { Standard Deviation }\end{array}$ & Median & $10^{\text {th }}-90^{\text {th }}$ Percentile \\
\hline $\begin{array}{c}\text { Member of S\&P } 500 \\
\text { at end of } 94\end{array}$ & $\begin{array}{c}.49 \\
(.50) \\
\end{array}$ & & \\
\hline $\begin{array}{c}\text { Member of MidCap } 400 \\
\text { at end of } 94\end{array}$ & $\begin{array}{l}.37 \\
(.48) \\
\end{array}$ & & \\
\hline $\begin{array}{l}\text { Market Capitalization } \\
\text { at end of } 1994 \text { in \$M }\end{array}$ & $\begin{array}{c}4051 \\
(8150)\end{array}$ & 1552 & $418-8569$ \\
\hline $\begin{array}{l}\text { Book Value of Assets at } \\
\text { end of } 1994 \text { in \$M }\end{array}$ & $\begin{array}{c}7512 \\
(22110)\end{array}$ & 1829 & $407-13873$ \\
\hline $\begin{array}{c}\text { Capital Expenditures / } \\
\text { Assets }\end{array}$ & $\begin{array}{l}.066 \\
(.052) \\
\end{array}$ & .056 & $.010-.130$ \\
\hline $\begin{array}{c}\text { Operating Income / } \\
\text { Assets }\end{array}$ & $\begin{array}{l}.156 \\
(.089)\end{array}$ & .150 & $.060-.256$ \\
\hline $\begin{array}{c}\text { Non-Operating Income / } \\
\text { Assets }\end{array}$ & $\begin{array}{c}.006 \\
(.012)\end{array}$ & .004 & $-.001-.018$ \\
\hline Market-to-book ratio & $\begin{array}{l}1.77 \\
(.93)\end{array}$ & 1.49 & $1.05-2.76$ \\
\hline $\begin{array}{l}\text { Long-term Debt / } \\
\text { Assets }\end{array}$ & $\begin{array}{l}.194 \\
(.172)\end{array}$ & .167 & $.006-.403$ \\
\hline $\begin{array}{c}\text { Stock Return } \\
\text { over } 1994\end{array}$ & $\begin{array}{l}.021 \\
(.296)\end{array}$ & .009 & $-.289-.321$ \\
\hline $\begin{array}{c}\text { Price Appreciation } \\
\text { over } 1995\end{array}$ & $\begin{array}{c}.246 \\
(.427)\end{array}$ & .208 & $-.173-.640$ \\
\hline
\end{tabular}

Notes:

Capital expenditures is Compustat annual data item 128. Operating income is Compustat annual data item 13. Non-operating income is Compustat annual data item 61. Long-term debt is Compustat annual data item 9. Capital expenditures, operating income, non-operating income, and debt outstanding are all measured in 1994 and are normalized by total assets at the end of 1994 (Compustat annual data item 6). Market-to-book ratio is the market value of common and preferred stock plus total liabilities divided by total assets, all measured at the end of 1994. Total liabilities and total assets reflect book values. The stock return includes both price appreciation and dividends and is calculated using the Center for Research in Securities Prices (CRSP) tapes. 